This is a self-archived version of an original article. This version may differ from the original in pagination and typographic details.

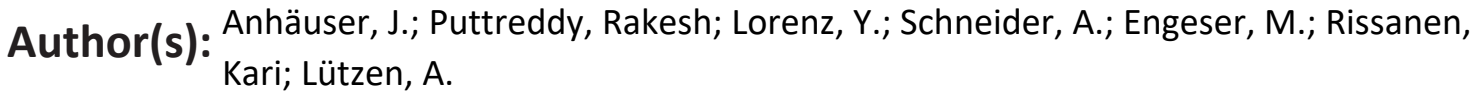

Title: Chiral self-sorting behaviour of [2.2]paracyclophane-based bis(pyridine) ligands

Year: 2019

Version: Accepted version (Final draft)

Copyright: (c) the Partner Organisations 2019

Rights: In Copyright

Rights url: http://rightsstatements.org/page/InC/1.0/?language=en

Please cite the original version:

Anhäuser, J., Puttreddy, R., Lorenz, Y., Schneider, A., Engeser, M., Rissanen, K., \& Lützen, A. (2019). Chiral self-sorting behaviour of [2.2]paracyclophane-based bis(pyridine) ligands. Organic Chemistry Frontiers, 6(8), 1226-1235. https://doi.org/10.1039/c9qo00155g 


\section{Organic Chemistry Frontiers}

ARTICLE

\section{Chiral self-sorting behaviour of [2.2]paracyclophane-based bis(pyridine) ligands}

Received 00th January 20xx Accepted 00th January 20xx DOI: $10.1039 / x 0 \times x 00000 x$ www.rsc.org/

\begin{abstract}
J. Anhäuser, ${ }^{a}$ R. Puttreddy, ${ }^{b}$ Y. Lorenz, ${ }^{a}$ A. Schneider, ${ }^{a}$ M. Engeser, ${ }^{a *}$ K. Rissanen, ${ }^{b *}$ A. Lützen ${ }^{a *}$
Two constitutionally isomeric chiral bis(pyridine) ligands based on planar chiral 4,15-difunctionalized [2.2]paracyclophanes were synthesized, the respective enantiomers were separated via HPLC on a chiral stationary phase, and their selfassembly behaviour upon coordination to palladium(II) ions was studied with regard to chiral self-sorting effects. As proven by NMR spectroscopy, mass spectrometry, CD spectroscopy, UV-Vis spectroscopy and X-ray crystallography both ligands form the expected dinuclear complexes upon coordination to cis-protected di- or tetravalent palladium(II) ions, respectively, however, with distinct differences concerning their chiral self-sorting ability.
\end{abstract}

Dedicated to Prof. Dr. Julius Rebek, Jr. on the occasion of his $75^{\text {th }}$ birthday.

\section{Introduction}

Despite the many examples known in literature of self-sorting phenomena in self-assembly processes of multicomponent mixtures, predicting the emerging aggregates in such systems is still a challenge. ${ }^{1}$ Nevertheless, there are some successful approaches known to achieve high-fidelity self-assembly, e.g. by selecting components of geometrical complementarity in size and shape leading either to self-discrimination ${ }^{2}$ (also called social self-sorting ${ }^{3}$ ) or self-recognition ${ }^{4}$ (also known as narcissistic self-sorting ${ }^{5}$ ). Chirality brings along more options for self-assembly processes as it can result in the formation of different stereoisomers. In terms of self-sorting, however, the use of racemic components sets a demanding task as enantiomers are mirror images which obviously do not vary in size and shape but only in their relative spatial orientation. ${ }^{[1 c]}$ Hence, they are highly similar competitors that are more difficult to distinguish in order to achieve self-sorting in a narcissistic or social manner. ${ }^{6}$ While well known in solid state, selfsorting of racemic mixtures in solution is much more challenging due to missing strong orientation and cooperative growth mechanism. ${ }^{7}$ Nevertheless, both of these scenarios have been reported in metallosupramolecular chemistry, albeit in a rather limited number using racemic ligands to form well-defined homochiral ${ }^{8,9}$ or heterochiral ${ }^{10,11}$ metallosupramolecular aggregates due to self-sorting effects.

\footnotetext{
Kekulé-Institut für Organische Chemie und Biochemie, Rheinische FriedrichWilhelms-Universität Bonn, Gerhard-Domagk-Str. 1, 53121 Bonn, Germany. E-Mail:marianne.engeser@uni-bonn.de,arne.luetzen@uni-bonn.de

b. University of Jyväskylä, Department of Chemistry, Nanoscience Center, P.O. Box

35, 40014 Jyväskylä, Finland

E-Mail: kari.t.rissanen@jyu.fi

† Electronic Supplementary Information (ESI) available: experimental procedures,

NMR spectra, mass spectra, HPLC chromatograms, CD spectra, UV-Vis spectra,

additional graphics of single crystal XRD data. For ESI and crystallographic data in

CIF or other electronic format see DOI: $10.1039 / \mathrm{x} 0 \mathrm{xx} 00000 \mathrm{x}$
}

The influence of different rigid scaffolds and binding motifs for diastereoselective self-assembly of metallosupramolecular aggregates has been analysed by varying scaffolds and binding moieties designed to form discrete metallosupramolecular aggregates. During these studies it turned out that the use of chelating metal-binding motifs usually ensures high diastereoselectivity and also a high degree of self-sorting in terms of narcissistic self-recognition, if the stereogenic element of the bridging ligand is not too far away from the metal binding sites and the ligands' structures show a reasonable degree of rigidity. ${ }^{8}$ Bridging ligands carrying monodentate metal-binding motifs proved to be much more challenging in this respect and subtle changes in the ligands' structure were demonstrated to have a huge impact on their self-sorting behaviour. ${ }^{9,11}$ With regard to repulsive interactions between peripheral bulky groups and rigidity, e.g. long flexible ligands often form mixtures of homochiral and heterochiral aggregates, whereas rigid non-crowded ligands tend to form heterochiral aggregates and on the contrary crowded ligands rather form homochiral complexes in a quantitative manner. ${ }^{6}$ Hence, there are several possibilities to adjust and fine-tune self-sorting processes by varying for example the overall size, the opening angle and the steric bulk of bridging $\mathrm{V}$-shaped ligands.

Herein, we report on the synthesis of rather rigid racemic and enantiomerically pure planar chiral ligands based on a pseudometa-difunctionalized [2.2]paracyclophane skeleton that have a rather wide opening angle and on their self-assembly behaviour to get further insight into the processes and factors that might rule their outcome. 


\section{Results and discussion}

\section{Synthesis and chiral resolution of bis(pyridine) ligands}

Readily accessible 4,15-diiodo[2.2]paracyclophane (1) forms the ideal starting point for a straightforward three step synthesis to both desired pyridine ligands ( $\mathbf{4}$ and $\mathbf{5}$ ) as outlined in Scheme $1 .{ }^{12}$

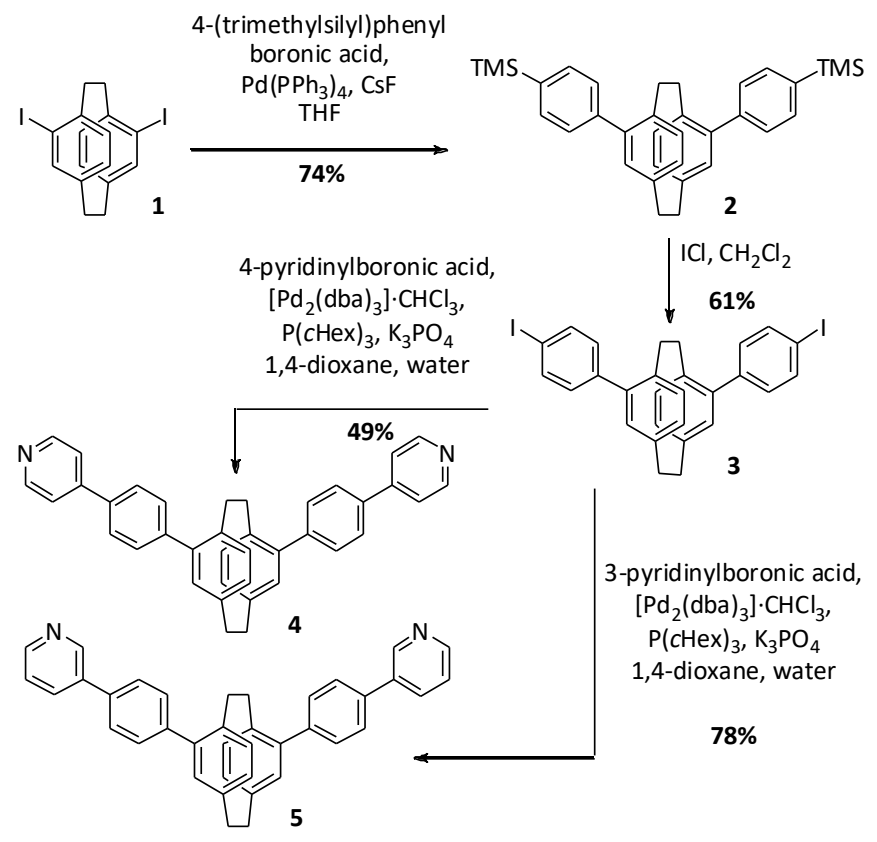

Scheme 1 Synthesis route to ligands $\mathbf{4}$ and $\mathbf{5}$.

Compound 1 could be easily transformed in a Suzuki cross-coupling with 4-(trimethylsilyl)phenylboronic acid into 4,15-bis(4-trimethylsilylphenyl)[2.2]paracyclophane (2). In order to convert $\mathbf{2}$ into a suitable reagent for a further Suzuki cross-coupling reaction, it was mixed with iodine monochloride to substitute the trimethylsilyl group by iodine giving 4,15-bis(4-iodophenyl)[2.2]paracyclophane (3). When compound 3 was reacted with 4-pyridinylboronic acid, ligand 4,15-bis(4-(pyridin-4-yl)phenyl)[2.2]paracyclophane (4) was formed. Accordingly, ligand 4,15-bis(4-(pyridin-3-yl)phenyl)[2.2]paracyclophane (5) was obtained from the reaction of 3-pyridinylboronic acid with $\mathbf{3}$ under Suzuki cross-coupling conditions.

Having received racemic target compounds $\mathbf{4}$ and $\mathbf{5}$ in this way the next task was to get them also in enantiomerically pure form. Therefore, we drew on our experience to separate planar chiral [2.2]paracyclophanes using HPLC on chiral stationary phases ${ }^{12,13}$ to resolve racemic 4,15-disubstituted [2.2] paracyclophanes $\mathbf{2}$ and $\mathbf{4}$ on analytical as well as on semi-preparative scale on a CHIRALPAK ${ }^{\circledR} \mathrm{IB}$ or a CHIRALPAK ${ }^{\circledast}$ IA stationary phase, respectively $(E S I+)$. Due to the latter, we received directly enantiomerically pure ligand 4 in sufficient quantity to perform the self-assembly experiments.

Our attempts to obtain good quality crystals of ligands $\mathbf{4}$ and $\mathbf{5}$ themselves for $\mathrm{X}$-ray structural determination were unsuccessful. However, 4 in the salt form, viz $(4+\mathrm{H})^{+} I_{3}{ }^{-}$, obtained from 1:1 mixture of methanol/water with addition of one drop of acetonitrile and hydroiodic acid, resulted in better quality single crystals. The X-ray crystal structure of $(\mathbf{4}+\mathrm{H})^{+} I_{3}{ }^{-}$confirmed that this enantiomer of $\mathbf{4}$ has
$\left(R_{\mathrm{p}}\right)$-configuration (see ESI + for a picture and further details of the structure).

Enantiomerically pure ligand $\mathbf{5}$ was synthesized in two steps from enantiomerically pure precursor 2 . The absolute configuration of the enantiomers could be assigned in a similar way by XRD analysis of an optically pure metal complex (vide infra and ESIt for details).

\section{Metal coordination studies}

Having achieved the synthesis of both ligands in racemic and enantiomerically pure form we then turned to their coordination behaviour towards palladium(II) ions as these are known to be among the most successful and simplistic coordination motifs for such kind of ligands to obtain either [(dppp $\left.{ }_{n} \mathrm{M}_{n} L_{n}\right]$ complexes from cis-protected divalent palladium(II) ions or $\left[\mathrm{M}_{n} \mathrm{~L}_{2 n}\right]$ complexes from tetravalent palladium(II) ions, respectively. ${ }^{14}$

Due to the pseudo-meta substitution pattern of the [2.2] paracyclophane both ligands have an opening angle of $120^{\circ} \pm 12^{\circ}$. Hence, ligand 5 carrying 3-pyridyl groups was expected to be well preorganized to form cage-like $\left[\mathrm{M}_{2} \mathrm{~L}_{4}\right]$ complexes upon exposure to tetravalent palladium(II) ions.

In order to test this assumption enantiomerically pure $\left(R_{\mathrm{p}}\right)-\mathbf{5}$ was mixed with half an equivalent of tetravalent $\left[\mathrm{Pd}\left(\mathrm{CH}_{3} \mathrm{CN}\right)_{4}\right]\left(\mathrm{BF}_{4}\right)_{2}$ in deuterated acetonitrile. ESI(+)-mass spectrometric studies proved the formation of the desired $\left[\mathrm{Pd}_{2}\left\{\left(R_{\mathrm{p}}\right)-5\right\}_{4}\right]\left(\mathrm{BF}_{4}\right)_{4}$ aggregate $(\mathrm{ESI}+)$. The ${ }^{1} \mathrm{H}$ NMR spectra of $\left(R_{\mathrm{p}}\right)-5$ and the corresponding $\left[\operatorname{Pd}_{2}\left\{\left(R_{\mathrm{p}}\right)-\right.\right.$ $\left.5\}_{4}\right]\left(\mathrm{BF}_{4}\right)_{4}$ complex formation are shown in Figure 2. Upon metal coordination, hydrogens ortho- to 3-pyridyl nitrogen experience the expected large downfield shift and DOSY experiments revealed that the size of the complex is in accordance with the expected $\mathrm{Pd}_{2} \mathrm{~L}_{4}-$ cage $(E S I+)$.

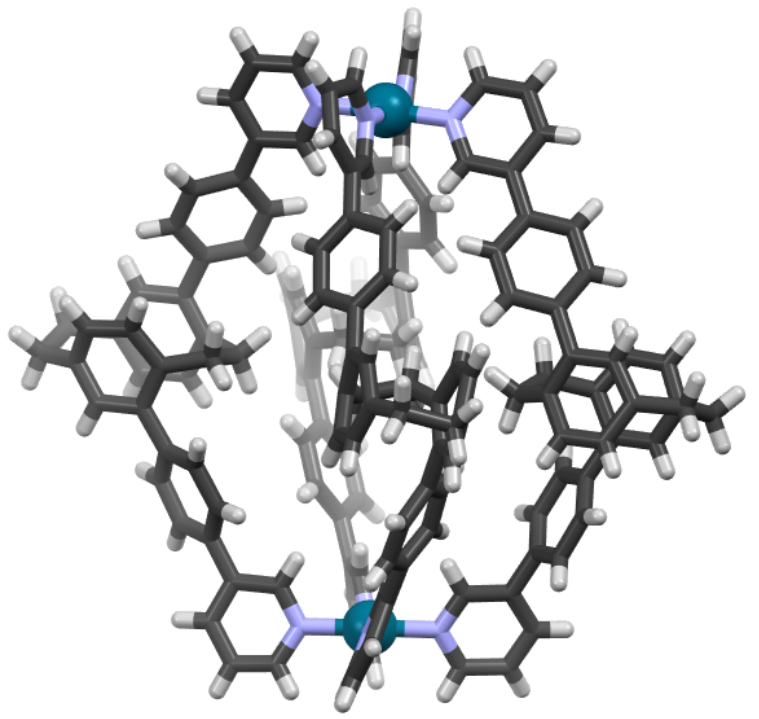

Fig. 1 X-ray crystal structure of homochiral metallosupramolecular dinuclear cage $\left[\mathrm{Pd}_{2}\left\{\left(R_{\mathrm{p}}\right)-5\right\}_{4}\right]\left(\mathrm{BF}_{4}\right)_{4}$ in capped stick model. Pd-centres are shown in ball \& stick model. (colour code: grey - carbon, white - hydrogen, blue - nitrogen, petrol - palladium; counterions have been omitted for clarity). 
Furthermore, X-ray crystallography also supports the expected $\mathrm{Pd}_{2} \mathrm{~L}_{4}$ cage-like structure of the homochiral metallosupramolecular aggregate. Suitable single crystals for $\mathrm{X}$-ray diffraction analysis were obtained by slow diffusion of diethyl ether into $\left[\operatorname{Pd}_{2}\left\{\left(R_{\mathrm{p}}\right)-5\right\}_{4}\right]\left(\mathrm{BF}_{4}\right)_{4}$ acetonitrile solution. Complex $\left[\mathrm{Pd}_{2}\left\{\left(R_{\mathrm{p}}\right)-5\right\}_{4}\right]\left(\mathrm{BF}_{4}\right)_{4}$ crystallizes in the tetragonal space group $\mathrm{P}_{1} 2_{1} 2$, with half a $\mathrm{Pd}_{2} \mathrm{~L}_{4}$ molecule in the asymmetric unit. Analysis of the Flack-parameter also confirmed that four ligands with an absolute $\left(R_{\mathrm{p}}\right)$-configuration coordinate two $\mathrm{Pd}(\mathrm{II})$ centres in square planar geometry and the structure is in good agreement with the highly symmetric species observed by ${ }^{1} \mathrm{H}$ NMR spectrum (Fig. 1). In addition the enantiomerically pure homochiral complexes could also be characterized by UV-Vis and $\mathrm{CD}$-spectroscopy $(\mathrm{ESI}+)$. Having proven the successful formation of the dinuclear homochiral assembly from the enantiomerically pure ligand $\mathbf{5}$ the next task was to investigate whether the racemic ligand (rac)-5 also forms dinuclear cages and whether these are formed with some degree of self-sorting. Again, ESI(+)-mass spectrometric experiments were performed first which unambiguously proved the formation of the desired dinuclear complexes (ESIt). We then turned to NMR spectroscopy to get further insight into the stereoselectivity of the self-assembly process. As shown in Figure 2, comparison of the ${ }^{1} \mathrm{H}-\mathrm{NMR}$ spectra clearly revealed that metal complexation did indeed take place in a quantitative manner as no signals of the free ligand could be detected anymore.
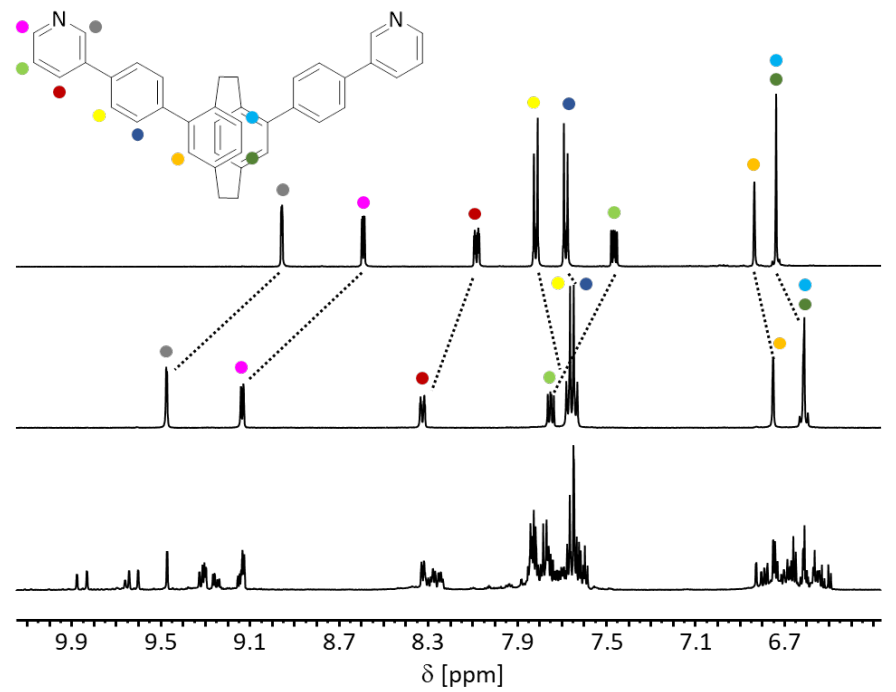

Fig. 2 Aromatic region of the ${ }^{1} \mathrm{H}$ NMR spectra recorded in deuterated acetonitrile at $298 \mathrm{~K}$ of ligand $\mathbf{5}$ (top), $\left[\mathrm{Pd}_{2}\left\{\left(R_{\mathrm{p}}\right)-5\right\}_{4}\right]\left(\mathrm{BF}_{4}\right)_{4}$ (middle) and the complex mixture of diastereomeric $\left[\mathrm{Pd}_{2}\left\{\mathbf{5}_{4}\right]\left(\mathrm{BF}_{4}\right)_{4}\right.$ complexes obtained from the self-assembly of $(\mathrm{rac})-5$ upon coordination to $\left[\mathrm{Pd}\left(\mathrm{CH}_{3} \mathrm{CN}\right)_{4}\right]\left(\mathrm{BF}_{4}\right)_{2}$ (bottom).

However, the self-assembly obviously does not occur with any significant degree of diastereoselectivity giving rise to a complex spectrum that most probably contains signals of all four possible diastereomeric complexes $\left[\mathrm{Pd}_{2}\left\{\left(R_{\mathrm{p}}\right)-5\right\}_{4}\right]\left(\mathrm{BF}_{4}\right)_{4}$ (and its enantiomer), $\left[\mathrm{Pd}_{2}\left\{\left(R_{\mathrm{p}}\right)-5\right\}_{3}\left\{\left(S_{\mathrm{p}}\right)-5\right\}_{1}\right]\left(\mathrm{BF}_{4}\right)_{4}$ (and its enantiomer), $\left[\operatorname{Pd}_{2}\left\{\left(R_{\mathrm{p}}\right)-5\right\}_{2}\left\{\left(S_{\mathrm{p}}\right)-\right.\right.$ $\left.\mathbf{5}_{2}\right\}_{2}\left(\mathrm{BF}_{4}\right)_{4}$ (with identically configurated ligands in trans-positions) and $\left[\operatorname{Pd}_{2}\left\{\left(R_{\mathrm{p}}\right)-5\right\}_{2}\left\{\left(S_{\mathrm{p}}\right)-5\right\}_{2}\right]\left(\mathrm{BF}_{4}\right)_{4}$ (with identically configurated ligands in cis-positions) (see Scheme 2 for a schematic presentation of the self-sorting behaviour of ligand $\mathbf{5}$ ).

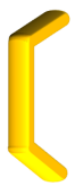

$\left(S_{p}\right)-5$

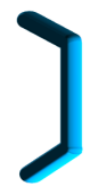

$\left(R_{\mathrm{p}}\right)-5$
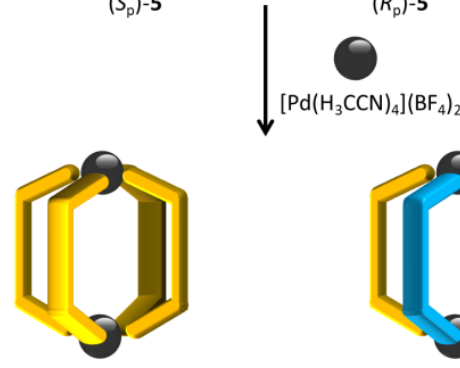

$\left[\mathrm{Pd}_{2}\left\{\left(\mathrm{~S}_{\mathrm{p}}\right)-5\right\}_{4}\right]\left(\mathrm{BF}_{4}\right)_{4}$ (+ enantiomer)

No noticeable chiral self-sorting!

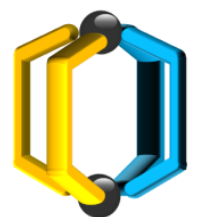

cis- $\left[\operatorname{Pd}_{2}\left\{\left(R_{\mathrm{p}}\right)-5\right\}_{2}\left\{\left(S_{\mathrm{p}}\right)-5\right\}_{2}\right]\left(\mathrm{BF}_{4}\right)_{4}$

Scheme 2 Schematic presentation of the self-assembly of ligand (rac)-5 which most probably leads to all four possible diastereomeric $M_{2} L_{4}$ assemblies without any noticeable chiral selfsorting.

This assumption was further corroborated by ${ }^{1} \mathrm{H}-2 \mathrm{D}-\mathrm{DOSY}$ NMR experiments. These revealed that all the signals observed in the spectrum of the complexes derived from ( $r a c)-5$ belong to species of similar size which is in accordance with the size determined for the homochiral dinuclear cage-like complex (ESIt). Thus, these experiments rule out that the additional signals might be caused by larger oligomeric or polymeric species which might not be detectable by ESI mass spectrometry. Hence, the self-assembly process is still selective in terms of aggregate composition but it is not in terms of diastereoselectivity and chiral self-sorting. In order to test if this result is due to a special solvent effect of the acetonitrile we also performed a series of ${ }^{1} \mathrm{H}$ NMR experiments in deuterated dimethyl sulfoxide (ESIt). Again, self-assembly of the dinuclear complexes occurred when (rac)-5 was employed, however, it occurred without any noticable diastereoselectivity, i.e. chiral self-sorting. In view of earlier results obtained for a similarly rigid ligand scaffold that was found to form such a dinuclear metallosupramolecular cage in a high-fidelity narcissistic self-sorting manner ${ }^{9 i}$ this result is rather surprising. A possible explanation might be that the current ligand structure contains a phenylene bridge instead of an ethynylene group between the central chiral element and the metal binding pyridine. This might lead to less distinct energetic differences between different conformers that differ in the relative orientation (twist) of the pyridyl ring and the paracyclophane core which have to be adopted in the different 
diastereomeric complexes. However, this has to be proven in future studies in due course compared to the situation in the previously reported BINOL-based bis(pyridine) ligand..$^{9 i}$

Interestingly, we observed an intriguing kinetic effect upon mixing preassembled enantiomerically pure complexes $\left[\operatorname{Pd}_{2}\left\{\left(R_{\mathrm{p}}\right)-5\right\}_{4}\right]\left(\mathrm{BF}_{4}\right)_{4}$ and $\left[\mathrm{Pd}_{2}\left\{\left(R_{\mathrm{p}}\right)-5\right\}_{4}\right]\left(\mathrm{BF}_{4}\right)_{4}$ in a 1:1 ratio: whereas a mixture in DMSO rearranged in a relatively short time upon slight heating to give rise to the equilibrated mixture observed before, the complexes proved to be kinetically much less labile in acetonitrile as it takes considerably more time to finally reach the equilibrium composition observed when starting from $(\mathrm{rac})-5$ and $\left[\mathrm{Pd}\left(\mathrm{CH}_{3} \mathrm{CN}\right)_{4}\right]\left(\mathrm{BF}_{4}\right)_{2}(\mathrm{ESI}+)$.

We then turned our attention to ligand 4. Here, we were especially keen on finding out if it could form dinuclear cyclic rhomb-like $M_{2} L_{2}-$ complexes upon coordination to cis-protected divalent $\left[\mathrm{Pd}(\mathrm{dppp})(\mathrm{OTf})_{2}\right]$ despite its rather large opening angle and if so whether some sort of chiral self-sorting occurs if (rac)-4 was employed.

Again, ESI(+)-mass spectrometric measurements were performed first and gave first indications of successful formation of the expected $\quad\left[\mathrm{Pd}_{2}(\mathrm{dppp})_{2}\left\{\left(R_{\mathrm{p}}\right)-4\right\}_{2}\right](\mathrm{OTf})_{4}$ aggregate, when one equivalent of $\left(R_{\mathrm{p}}\right)-\mathbf{4}$ was mixed with one equivalent of cis-protected bivalent $[\mathrm{Pd}(\mathrm{dppp})](\mathrm{OTf})_{2}$ in deuterated acetonitrile (ESI +$)$. The ESI mass spectra of $\left[\operatorname{Pd}_{2}(\mathrm{dppp})_{2}\left\{\left(R_{\mathrm{p}}\right)-4\right\}_{2}\right](\mathrm{OTf})_{4}$ showed the typical series of intact rhombs obtained by stripping off two, three or all four triflate counter ions (ESI $\dagger$ ). Fragmentation into smaller ions could be avoided almost completely by careful tuning of the ESI parameters.

Comparison of NMR spectra of ligand $\left(R_{\mathrm{p}}\right)-4$ and its complexes also indicated successful formation of $\left[\operatorname{Pd}_{2}(\mathrm{dppp})_{2}\left\{\left(R_{\mathrm{p}}\right)-4\right\}_{2}\right](\mathrm{OTf})_{4}$, when one equivalent of $\left(R_{\mathrm{p}}\right)-\mathbf{4}$ was mixed with one equivalent of cisprotected bivalent $[\mathrm{Pd}(\mathrm{dppp})](\mathrm{OTf})_{2}$ in deuterated acetonitrile (see Figure 3 and $\mathrm{ESI} \dagger$ ). Furthermore, the optically pure homochiral metallosupramolecular rhombs could also be characterized by UVVis and CD spectroscopy.

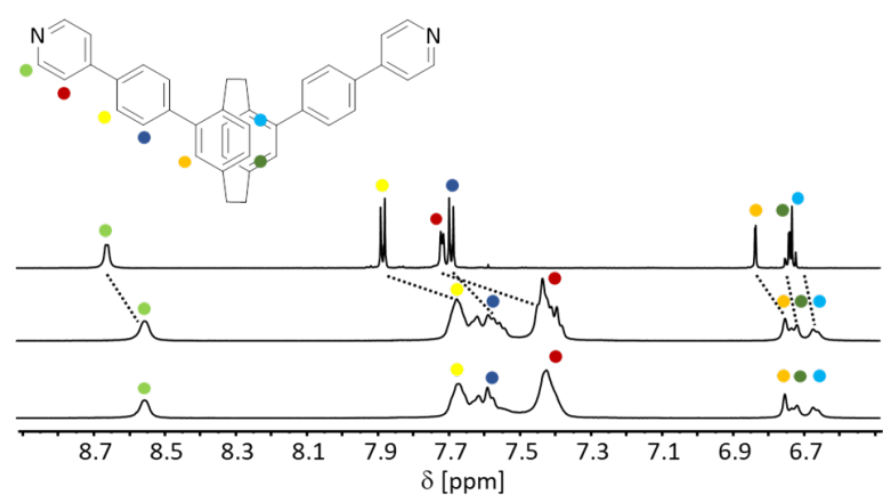

Fig. 3 Aromatic region of ${ }^{1} \mathrm{H}$ NMR spectra recorded in deuterated acetonitrile at $298 \mathrm{~K}$ of ligand 4 (top), $\left[\mathrm{Pd}_{2}(\mathrm{dppp})_{2}\left\{\left(R_{\mathrm{p}}\right)-4\right\}_{2}\right](\mathrm{OTf})_{4}$ and the racemic mixture of $\left[\mathrm{Pd}_{2}(\mathrm{dppp})_{2}\left\{\left(R_{\mathrm{p}}\right)-4\right\}_{2}\right](\mathrm{OTf})_{4}$ and $\left[\operatorname{Pd}_{2}(\mathrm{dppp})_{2}\left\{\left(\mathrm{~S}_{\mathrm{p}}\right)-4\right\}_{2}\right](\mathrm{OTf})_{4}$ obtained from the self-assembly of (rac)4 upon coordination to [Pd(dppp)](OTf) $)_{2}$ (bottom).

Then, $(\mathrm{rac})-\mathbf{4}$ was combined with $\left[\mathrm{Pd}(\mathrm{dppp})(\mathrm{OTf})_{2}\right]$ in a 1:1 ratio in deuterated acetonitrile to study its self-sorting behaviour during self-assembly. ESI(+)-mass spectrometry proved that it also forms the desired dinuclear complexes as the enantiomerically pure ligand does. Analysis of the ${ }^{1} \mathrm{H}, \mathrm{H}, \mathrm{H}-\mathrm{COSY}$ and ${ }^{1} \mathrm{H}-2 \mathrm{D}$-DOSY NMR spectra $(E S I+)$ revealed only one set of signals that was virtually identical with that recorded for the homochiral assembly $\left[\mathrm{Pd}_{2}(\mathrm{dppp})_{2}\left\{\left(R_{\mathrm{p}}\right)-\right.\right.$ $\left.4\}_{2}\right](\mathrm{OTf})_{4}$ (Figures 3 and 4).

In order to further prove that this set is indeed caused by the racemic mixture of the homochiral enantiomers we also compared the respective ${ }^{31 P}$ NMR spectra (Figure 4). Usually, signal shifts of different diastereomers are much better separated in ${ }^{31} \mathrm{P}$ than in the ${ }^{1} \mathrm{H}$ NMR spectra. All of these spectral information clearly indicated that the self-assembly occurred under high-fidelity narcissistic self-sorting leading exclusively to a racemic mixture of homochiral aggregates.

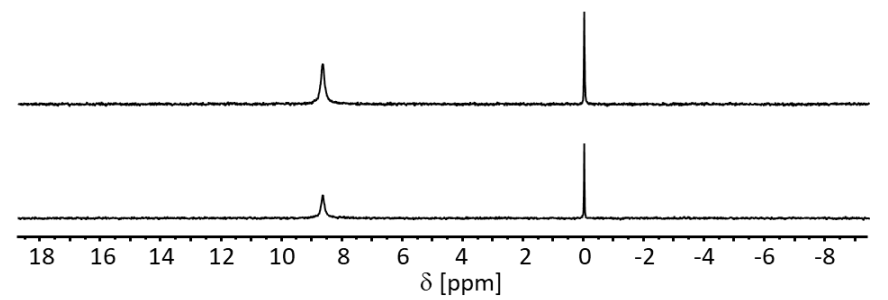

Fig. 4 31P NMR spectra recorded in deuterated acetonitrile at $298 \mathrm{~K}$ of $\left[\mathrm{Pd}_{2}(\mathrm{dppp})_{2}\left\{\left(R_{\mathrm{p}}\right)-4\right\}_{2}\right](\mathrm{OTf})_{4}$ (top) and $\left[\mathrm{Pd}_{2}(\mathrm{dppp})_{2}\{(\mathrm{rac})\right.$ 4 $\left.\}_{2}\right](\mathrm{OTf})_{4}$ (bottom).

Final proof for the narcissistic self-sorting was obtained from single crystal XRD analysis. Fortunately, single crystals of the racemic mixture of $\left[\mathrm{Pd}_{2}(\mathrm{dppp})_{2}\left\{\left(R_{\mathrm{p}}\right)-4\right\}_{2}\right](\mathrm{OTf})_{4}$ and $\quad\left[\mathrm{Pd}_{2}(\mathrm{dppp})_{2}\left\{\left(\mathrm{~S}_{\mathrm{p}}\right)-\right.\right.$ $\left.\left.{ }_{4}\right\}_{2}\right](\mathrm{OTf})_{4}$ suitable for $\mathrm{X}$-ray diffraction analysis could be obtained by slow diffusion of cyclopentane into a solution of ( $\mathrm{rac}$-4 4 and $\left[\mathrm{Pd}(\mathrm{dppp})(\mathrm{OTf})_{2}\right]$ in tetrahydrofuran/methanol with few drops of dichloromethane and acetonitrile. The complexes crystallize in the monoclinic centrosymmetric space group $\mathrm{C} / \mathrm{c}$ confirming racemic mixed crystal and, as expected, the [2+2] aggregate of V-shaped ligand 4 and $\left[\mathrm{Pd}(\mathrm{dppp})(\mathrm{OTf})_{2}\right]$ resembles a molecular rhomb (Figure 5).

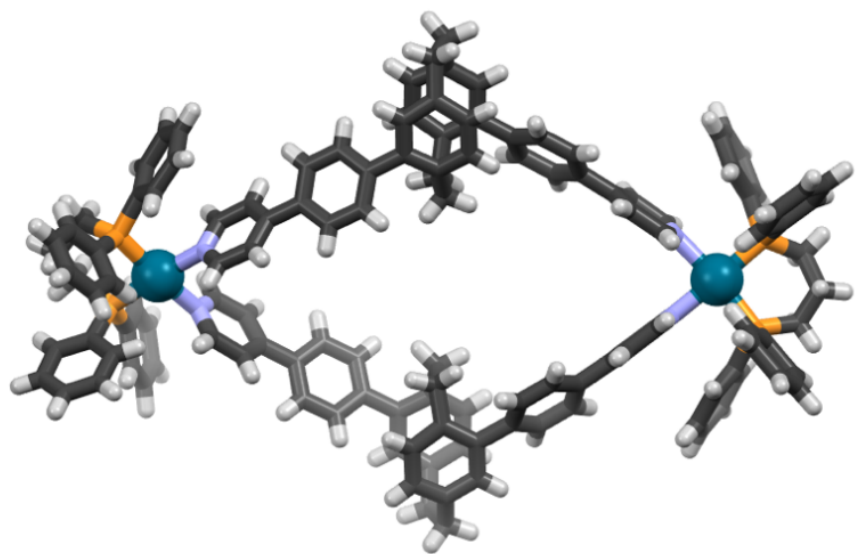

Fig. 5 X-ray crystal structure of homochiral metallosupramolecular dinuclear rhomb $\left[\mathrm{Pd}_{2}(\mathrm{dppp})_{2}\left\{\left(R_{\mathrm{p}}\right)-4\right\}_{2}\right](\mathrm{OTf})_{4}$ in capped stick model. $\mathrm{Pd}(\mathrm{II})$-centres are shown in ball \& stick model. (only one enantiomer of the racemic mixture is shown, colour code: grey - carbon, white - hydrogen, blue - nitrogen, orange - phosphorus, petrol palladium ; counterions and solvent molecules have been omitted for clarity). 
Furthermore, special solvent effects could be ruled out by performing additional mass spectrometric and ${ }^{1} \mathrm{H}$ NMR experiments in a 1:1 mixture of deuterated acetonitrile and dichloromethane $(\mathrm{ESI}+)$ that revealed the same behaviour of $(\mathrm{rac})-\mathbf{4}$ in this environment.

Like observed for ( $r a c)-5$ the self-sorting behaviour of ( $r a c)-4$ was also rather unexpected (see Scheme 3 for a schematic presentation of the chiral self-sorting behaviour of ligand (rac)-4).

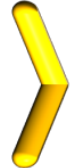

$\left(S_{p}\right)-4$

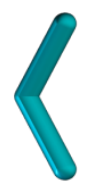

$\left(R_{\mathrm{p}}\right)-4$

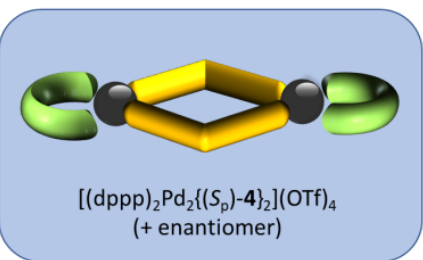

$\left[\mathrm{Pd}(\mathrm{dppp})(\mathrm{OTf})_{2}\right]$

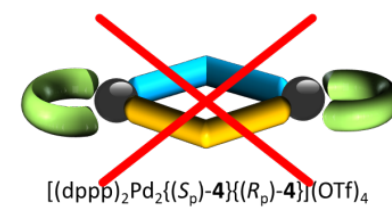

not observed

Exclusive narcissistic chiral self-sorting!

Scheme 3 Schematic presentation of the self-assembly of ligand (rac)-4 which occurs in a high-fidelity narcissistic chiral self-sorting manner.

Usually, rigid V-shaped ligands with similar wide opening angle were reported to show hardly any diastereoselective chiral selfsorting. Nevertheless, (rac)-4 self-assembled in a very selective narcissistic self-sorting manner. Although the reason for this surprising difference it not yet clear, it shows impressively how putatively subtle changes in the ligands' structure might cause a drastically different self-assembly behaviour.

\section{Conclusions}

In summary, we synthesized four new planar chiral compounds based on the pseudo-meta-disubstituted [2.2]paracyclophane core including the two constitutionally isomeric (bis)pyridine ligands $\mathbf{4}$ an $\mathbf{5}$. These chiral compounds could be obtained in racemic and enantiomerically pure form by either directly resolving them via HPLC on a chiral stationary phase (4 and $\mathbf{2}$ ) or by synthesizing them from enantiomerically pure 2 (3 and 5). The absolute configuration of ligands 4 and $\mathbf{5}$ could be assigned via anomalous $\mathrm{X}$-ray diffraction analysis.

The enantiomerically pure $V$-shaped ligands self-assemble into optically pure homochiral dinuclear rhomb-shaped $\left[\mathrm{Pd}_{2}(\mathrm{dppp})_{2}\left\{\left(R_{\mathrm{p}}\right)-4\right\}_{2}\right](\mathrm{OTf})_{4}$ and cage-like $\left[\mathrm{Pd}_{2}\left\{\left(R_{\mathrm{p}}\right)-5\right\}_{4}\right]\left(\mathrm{BF}_{4}\right)_{4}$ upon coordination to $[\mathrm{Pd}(\mathrm{dppp})](\mathrm{OTf})_{2}$ or $\left[\mathrm{Pd}\left(\mathrm{CH}_{3} \mathrm{CN}\right)_{4}\right]\left(\mathrm{BF}_{4}\right)_{2}$, respectively. These aggregates could be characterized by NMR spectroscopy, mass spectrometry, CD spectroscopy, UV-Vis spectroscopy and X-ray crystallography.

Interestingly, the two ligands showed very different selfsorting behaviour: whereas self-assembly of (rac)-5 into $\mathrm{M}_{2} \mathrm{~L}_{4}$ cages occurred without any noticeable diastereoselectivity, (rac)-4 self-assembles into a racemic mixture of homochiral $\mathrm{M}_{2} \mathrm{~L}_{2}$ rhombs in a high-fidelity narcissistic self-sorting manner. In view of earlier results obtained with similarly rigid dissymmetric bis(pyridine) ligands this is rather surprising since the opposite behaviour would have been expected with regard to the wide opening angle of the ligands of $120^{\circ} \pm 12^{\circ}$. Although the exact reasons are not yet clear the influence of the phenylene bridges on the conformational behaviour of the ligands and the resulting preferred relative orientation of the [2.2]paracyclophane core and the pyridine rings might play an important role that has to examined in more detail employing other rigid dissymmetric cores in the future. Nevertheless, the results of this study clearly demonstrate how comparatively subtle changes in the ligands' structures might cause a drastically different self-assembly behaviour in terms of chiral self-sorting effects.

\section{Conflicts of interest}

There are no conflicts to declare.

\section{Experimental section}

\section{General experimental information}

All reactions with air and moisture sensitive compounds were performed under argon atmosphere using standard Schlenk techniques, oven-dried glassware and dry solvents.

The following chemicals were obtained from commercial sources and used as received: 4-(trimethylsilyl)phenylboronic acid, caesium fluoride, tetrakis(triphenylphosphine)palladium(0), iodine monochloride, 4-pyridinylboronic acid, tricyclohexylphosphine, potassium phosphate, 3-pyridinylboronic acid, tetrakis(acetonitrile)palladium(II) tetrafluoroborate.

The following chemicals were synthesized according to known literature procedures: 4,15-diiodo[2.2] paracyclophane ((rac)-1),12 tris(dibenzylideneacetone)dipalladium(0)-chloroform, ${ }^{15}$ [1,3-bis(diphenylphosphino)propane]palladium(II) triflate. ${ }^{16,17}$

All solvents were obtained from commercial sources. Dry solvents were obtained from the solvent purification system MS-SPS 800 from $M$ Braun. Other reaction solvents and solvents for specific rotation value, UV-Vis or CD measurements were solvents of p.a. grade. For flash column chromatography freshly distilled solvents of technical grade and for high performance liquid chromatography solvents of HPLC grade were used.

Thin-layer chromatography was performed on silica gel-coated aluminium plates with fluorescent indicator F254 from Merck. Detection was done by UV-light ( 254 and $366 \mathrm{~nm}$ ).

Products were purified by flash column chromatography on silica gel 60 (particle size $0.040-0.063 \mathrm{~mm}$ ) from Merck or on reversed phase silica gel (C18-RP, 17\% C, 0.048-0.065 mm) from Acros Organics.

${ }^{1} \mathrm{H},{ }^{13} \mathrm{C},{ }^{19} \mathrm{~F}, 31 \mathrm{P}, \mathrm{H}, \mathrm{H}$-COSY, HSQC, HMBC and ${ }^{1} \mathrm{H}$-2D-DOSY NMR experiments were performed on Bruker Avance I 400 spectrometer, 
a Bruker Avance I 500 spectrometer, a Bruker Avance III HD 500 spectrometer with a Prodigy cryo probe or a Bruker Avance III HD 700 spectrometer with a cryo probe. ${ }^{1} \mathrm{HNMR}$ chemical shifts are reported relative to residual non-deuterated solvent as internal standard. ${ }^{13} \mathrm{CNMR}$ chemical shifts are reported relative to deuterated solvent as internal standard. ${ }^{19} \mathrm{~F}$ and ${ }^{31} \mathrm{P}$ chemical shifts are reported relative to a mixture of trifluoroacetic acid- $\mathrm{d}_{1}\left({ }^{19} \mathrm{~F}: \delta=\right.$ $-76.6 \mathrm{ppm}$ ) and phosphoric acid- $\mathrm{d}_{3}$ (31 $\mathrm{p}: \delta=0.0 \mathrm{ppm}$ ) in $\mathrm{D}_{2} \mathrm{O}$ as external standard using a Wilmad $^{\circledR}$ sample tube with coaxial insert. All shifts are reported on the $\delta$ scale in ppm and NMR multiplicities are abbreviated as s (singlet), $d$ (doublet), t (triplet), dd (doublet of doublets), ddd (doublet of doublet of doublets) or $m$ (multiplet). Coupling constants $J$ are reported in Hertz. For the numbering schemes of the individual nuclei see ESIt. All spectra were processed using the MestReNova 8.0.1 program from Mestrelab. ${ }^{1} \mathrm{H}-2 \mathrm{D}-D O S Y$ NMR spectra were evaluated using the software Topspin 3.5 from Bruker and the Stokes-Einstein equation, normally used for spherical particles, with a correction factor for ellipsoids. ${ }^{18}$ (High-resolution) electrospray ionization mass spectra in positive mode (ESI(+)-MS) were measured on an Orbitrap $X L$ mass spectrometer from Thermo Fisher Scientific or a micrOTOF-Q quadrupole/time-of-flight mass spectrometer from Bruker Daltonics. Electron ionization mass spectra (EI-MS) were measured on a MAT $95 X L$ or a MAT 90 sector field mass spectrometer from Thermo Finnigan.

Elementary analyses were performed on a Vario EL elemental analyzer from Heraeus.

Melting points were determined with a DigiMelt MPA 161 instrument from Stanford Research Systems.

UV-Vis spectra were measured on a Specord 200 instrument from Analytik Jena and analysed using the software WinASPECT 1.7.2.0. Quartz glass cuvettes from Hellma Analytics with a layer thickness of $10 \mathrm{~mm}$ (solutions of ligand precursors/ligands) and $0.01 \mathrm{~mm}$ (complex solutions) were used.

Circular dichroism spectra were measured on a J-810 spectrometer from Jasco. Quartz glass cuvettes from Hellma Analytics with a layer thickness of $1 \mathrm{~mm}$ (solutions of ligand precursors/ligands) and $0.01 \mathrm{~mm}$ (complex solutions) were used.

Specific rotation values were measured on an Anton Paar Model MCP 150 polarimeter with a standard wavelength of $589 \mathrm{~nm}$ using a cuvette with a layer thickness of $100 \mathrm{~mm}$.

High performance liquid chromatography on analytical scale was performed on a PLATINblue HPLC system from Knauer, equipped with two pumps, an online degasser and a photodiode array detector PDA-1 with a deuterium and tungsten-halogen lamp (190$1000 \mathrm{~nm})$. For analytical HPLC resolution a $C H I R A L P A K^{\circledR}$ IA column $(4.6 \mathrm{~mm} \varnothing, 250 \mathrm{~mm})$ by Daicel or a CHIRALPAK ${ }^{\circledR}$ IB column (4.6 $\mathrm{mm} \varnothing, 250 \mathrm{~mm}$ ) by Daicel was used. High performance liquid chromatography on semi-preparative scale was performed on an Azura HPLC system from Knauer, equipped with a binary HPG pump $P$ 6.1L, an online degasser, a multi wavelength detector $M W L$ 2.1L with deuterium lamp (190-700 $\mathrm{nm})$ and a fraction collector. For semi-preparative HPLC resolution a CHIRALPAK ${ }^{\circledast}$ IA column $(20 \mathrm{~mm} \varnothing, 250 \mathrm{~mm})$ by Daicel or a CHIRALPAK ${ }^{\circledR}$ IB column (20 $\mathrm{mm} \varnothing, 250 \mathrm{~mm}$ ) by Daicel was used.

\section{Synthetic procedures}

4,15-Bis-(4-trimethylsilylphenyl)[2.2]paracyclophane (2). Under an atmosphere of argon, (rac)-1 $\mathbf{1}^{12}(900 \mathrm{mg}, 1.96 \mathrm{mmol}, 1.00$ eq.), 4-(trimethylsilyl)phenylboronic acid $(875 \mathrm{mg}, 4.51 \mathrm{mmol}, 2.30 \mathrm{eq}$.), caesium fluoride (1.79 $\mathrm{mg}, \quad 11.8 \mathrm{mmol}, 6.00 \mathrm{eq}$.) and tetrakis(triphenylphosphine)palladium(0) $(226 \mathrm{mg}, \quad 0.196 \mathrm{mmol}$, $10.0 \mathrm{~mol} \%)$ were dissolved in dry tetrahydrofuran $(75 \mathrm{~mL})$. The reaction mixture was degassed at room temperature and then heated to reflux for $48 \mathrm{~h}$. After cooling to room temperature the solution was quenched by the addition of saturated aqueous ethylenediaminetetraacetic acid disodium salt solution and dichloromethane. The mixture was extracted with dichloromethane. The combined organic layers were washed with brine, dried with anhydrous magnesium sulphate and the solvent was removed under reduced pressure. The crude product was subjected to flash column chromatography on silica gel (cyclohexane/ dichloromethane $10: 1)$ to give (rac)-2 (733 mg, $1.45 \mathrm{mmol}, 74 \%)$ as a white solid. ${ }^{1 \mathrm{H}} \mathrm{NMR}\left(500.1 \mathrm{MHz}, \mathrm{CDCl}_{3}, 298 \mathrm{~K}\right): \delta[\mathrm{ppm}]=7.63-$ 7.60 (m, 4H, H-19), 7.49-7.46 (m, 4H, H-18), 6.72 (d, 2H, H-5, H-16, $\left.{ }^{4} J_{5,7}=4 J_{16,12}=1.9 \mathrm{~Hz}\right), 6.68\left(\mathrm{~d}, 2 \mathrm{H}, \mathrm{H}-8, \mathrm{H}-13,{ }^{3} J_{8,7}=3 J_{13,12}=7.8 \mathrm{~Hz}\right)$, $6.56\left(\mathrm{dd}, 2 \mathrm{H}, \mathrm{H}-7, \mathrm{H}-12,{ }^{3} J_{7,8}={ }^{3} J_{12,13}=7.8 \mathrm{~Hz},{ }^{4} J_{7,5}={ }^{4} J_{12,16}=1.9 \mathrm{~Hz}\right)$, 3.26-3.07 (m, 6H, H-1, H2, H-9, H-10), 2.64-2.55 (m, 2H, H-1, H-2), 0.33 (s, $18 \mathrm{H}, \mathrm{H}-21) .{ }^{13} \mathrm{C}$ NMR (125.8 MHz, CDCl $\left.3,298 \mathrm{~K}\right)$ : $\delta$ [ppm] $=142.7(\mathrm{C}-4, \mathrm{C}-15), 141.7(\mathrm{C}-17), 139.6(\mathrm{C}-6, \mathrm{C}-11), 138.8$ (C-20), 137.6 (C-3, C-14), 133.7 (C-19), 132.5 (C-8, C-13), 132.0 (C-5, C-16), 131.5 (C-7, C-12), 129.1 (C-18), 35.3 (C-9, C-10), 33.5 (C-1, C-2), -0.84 (C-21). MS (EI) $m / z$ (intens. \%): 504.3 (73) [2 [ ${ }^{+*}, 489.3$ (11) $\left[2-\mathrm{CH}_{3}\right]^{+}, 416.2(33)\left[2-\mathrm{C}_{4} \mathrm{H}_{12} \mathrm{Si}\right]^{+}, 356.3$ (7) $\left[2-\mathrm{C}_{9} \mathrm{H}_{12} \mathrm{Si}\right]^{+}, 237.2$ (58) [2- $\left.\mathrm{C}_{18} \mathrm{H}_{23} \mathrm{Si}\right]^{+}, 73.1(100)\left[\mathrm{C}_{3} \mathrm{H}_{9} \mathrm{Si}\right]^{+}$; HR-MS (EI) $\mathrm{m} / \mathrm{z}$ : calculated for $\mathrm{C}_{34} \mathrm{H}_{40} \mathrm{Si}_{2}$ [2] [ : 504.2669, found: 504.2672. Elementary analysis: calculated for $\mathrm{C}_{34} \mathrm{H}_{40} \mathrm{Si}_{2}$ : C: 80.89, H: 7.99, found: C: $80.70, \mathrm{H}: 7.98$. Melting point: $111^{\circ} \mathrm{C}$. $\mathrm{R}_{\mathrm{f}}$ (cyclohexane/dichloromethane 5:1): 0.48 . UV-Vis $\left(\mathrm{CH}_{3} \mathrm{CN}, \mathrm{c}=1.98 \mu \mathrm{M}\right): \lambda[\mathrm{nm}]=233,285$. HPLC (analytical, CHIRALPAK ${ }^{\circledast}$ IB, methanol/ethanol (90:10 v/v), $\left.1 \mathrm{~mL} / \mathrm{min}\right):\left(R_{\mathrm{p}}\right)-2 t_{R}$ $=4.55 \mathrm{~min},\left(S_{\mathrm{p}}\right)-2 t_{R}=4.98 \mathrm{~min}$. HPLC semi-preparative recycling mode (CHIRALPAK ${ }^{\circledast} \mathrm{IB}$, methanol/ethanol (90:10 v/v), $\left.18 \mathrm{~mL} / \mathrm{min}\right)$ : $\left(R_{\mathrm{p}}\right)-\mathbf{2}$ 99\% ee, $\left(S_{\mathrm{p}}\right)-\mathbf{2}$ 97\% ee. Specific rotation: $(-)-\left(R_{\mathrm{p}}\right)-\mathbf{2}:[\alpha]_{D}^{23}=$ $-442^{\circ}\left(\mathrm{c}=2.00 \mathrm{mg} / \mathrm{mL}=3.96 \mathrm{mM}, \mathrm{CH}_{2} \mathrm{Cl}_{2}\right),(+)-\left(S_{\mathrm{p}}\right)-2:[\alpha]_{D}^{23}=+420^{\circ}$ (c $\left.=2.00 \mathrm{mg} / \mathrm{mL}=3.96 \mathrm{mM}, \mathrm{CH}_{2} \mathrm{Cl}_{2}\right) . \mathrm{CD}\left(\mathrm{CH}_{3} \mathrm{CN}, \mathrm{c}=198 \mu \mathrm{M}\right): \lambda[\mathrm{nm}]$ $(\Delta \varepsilon[\mathrm{L} /(\mathrm{mol} \mathrm{cm})])=\left(R_{\mathrm{p}}\right)-\mathbf{2}: 214(-76), 228(+36), 292(-88), 237$ (+11), $251(-91) ;\left(S_{\mathrm{p}}\right)-2$ : $214(+84), 228(-36), 237(+13), 251(-100)$, $292(+98)$.

4,15-Bis-(4-iodophenyl)[2.2]paracyclophane (3). Under an atmosphere of argon, $(\mathrm{rac})-/\left(R_{\mathrm{p}}\right)-/\left(S_{\mathrm{p}}\right)-2 \quad(350 \mathrm{mg}, 0.693 \mathrm{mmol}$, 1.00 eq.) was dissolved in dry dichloromethane $(5 \mathrm{~mL})$ and cooled to $0{ }^{\circ} \mathrm{C}$. At $0{ }^{\circ} \mathrm{C}$ iodine monochloride solution $(1.40 \mathrm{~mL}, 1 \mathrm{M}$ in dichloromethane, $1.40 \mathrm{mmol}, 2.00$ eq.) was added slowly over $45 \mathrm{~min}$ and the red reaction mixture was stirred at $0{ }^{\circ} \mathrm{C}$ for further $45 \mathrm{~min}$. Then, it was warmed up to room temperature and stirred for another hour. Subsequently, saturated aqueous sodium sulphite solution was added and the mixture was stirred until discolouration. The phases were separated and the aqueous phase was extracted with dichloromethane. The combined organic layers were washed with brine, dried with anhydrous magnesium sulphate and the solvent was removed under reduced pressure. The crude product was subjected to flash column chromatography on silica gel (cyclohexane/dichloromethane 20:1) to give (rac)-/( $\left.R_{p}\right)-/\left(S_{p}\right)-3$ (260 mg, $0.425 \mathrm{mmol}, 61 \%$ ) as a white solid. ${ }^{1} \mathrm{H}$ NMR $(500.1 \mathrm{MHz}$, $\left.\mathrm{CDCl}_{3}, 298 \mathrm{~K}\right): \delta[\mathrm{ppm}]=7.82-7.78(\mathrm{~m}, 4 \mathrm{H}, \mathrm{H}-19), 7.24-7.21(\mathrm{~m}, 4 \mathrm{H}$, 
$\mathrm{H}-18), 6.65\left(\mathrm{~d}, 2 \mathrm{H}, \mathrm{H}-5, \mathrm{H}-16,{ }^{4} J_{5,7}=4 J_{16,12}=1.9 \mathrm{~Hz}\right), 6.64(\mathrm{~d}, 2 \mathrm{H}, \mathrm{H}-8$, $\mathrm{H}-13,3 J_{8,7}=3 J_{13,12}=7.8 \mathrm{~Hz}$ ), $6.55\left(\mathrm{dd}, 2 \mathrm{H}, \mathrm{H}-7, \mathrm{H}-12,3 J_{7,8}=3 J_{12,13}=\right.$ $\left.7.8 \mathrm{~Hz},{ }^{4} J_{7,5}={ }^{4} J_{12,16}=1.9 \mathrm{~Hz}\right), 3.25-3.18(\mathrm{~m}, 2 \mathrm{H}, \mathrm{H}-9, \mathrm{H}-10), 3.16-3.05$ (m, 4H, H-1, H-2, H-9, H-10), 2.56-2.48 (m, 2H, H-1, H-2). ${ }^{13} \mathrm{C}$ NMR $\left(125.8 \mathrm{MHz}, \mathrm{CDCl}_{3}, 298 \mathrm{~K}\right): \delta$ [ppm] = 141.5 (C-4, C-15), 140.7 (C-17), 140.0 (C-6, C-11), 137.9 (C-19), 137.3 (C-3, C-14), 132.4 (C-8, C-13), 131.8 (C-5, C-16), 131.6 (C-7, C-12), 131.6 (C-18), 93.0 (C-20), 35.2 (C-9, C-10), 33.5 (C-1, C-2). MS (EI) $m / z$ (intens. \%): 611.8 (47) [3]+", $485.0(58)[3-1]^{+}, 304.9(45)\left[3-\mathrm{C}_{14} \mathrm{H}_{12} \mathrm{I}\right]^{+}, 179.0(100)\left[3-\mathrm{C}_{14} \mathrm{H}_{11} \mathrm{I}_{2}\right]^{+}$ HR-MS (EI) $m / z$ : calculated for $\mathrm{C}_{28} \mathrm{H}_{22} \mathrm{I}_{2}$ [3] $]^{+*}: 611.9811$, found: 611.9816. Elementary analysis: calculated for $\mathrm{C}_{28} \mathrm{H}_{22} \mathrm{I}_{2} \cdot 1 / 3 \mathrm{C}_{6} \mathrm{H}_{6}$ : C: 56.45, H: 3.79 , found: C: $56.37, \mathrm{H}: 4.18$. Melting point: $229^{\circ} \mathrm{C}$. $\mathrm{R}_{\mathrm{f}}$ (cyclohexane/dichloromethane 5:1): 0.47. UV-Vis $\left(\mathrm{CH}_{3} \mathrm{CN}, \mathrm{c}=16.3\right.$ $\mu \mathrm{M}): \lambda[\mathrm{nm}]=245,288$. Specific rotation: $(-)-\left(R_{\mathrm{p}}\right)-3:[\alpha]_{D}^{23}=-354^{\circ}(\mathrm{c}$ $\left.=2.00 \mathrm{mg} / \mathrm{mL}=4.90 \mathrm{mM}, \mathrm{CH}_{2} \mathrm{Cl}_{2}\right),(+)-\left(S_{\mathrm{p}}\right)-3:[\alpha]_{D}^{23}=+370^{\circ}$ ( $\left.\mathrm{c}=2.00 \mathrm{mg} / \mathrm{mL}=4.90 \mathrm{~mm}, \mathrm{CH}_{2} \mathrm{Cl}_{2}\right) . \mathrm{CD}\left(\mathrm{CH}_{3} \mathrm{CN}, \mathrm{c}=163 \mu \mathrm{M}\right): \lambda[\mathrm{nm}]$ $(\Delta \varepsilon[\mathrm{L} /(\mathrm{mol} \mathrm{cm})])=\left(R_{\mathrm{p}}\right)-3: 217(-78), 231(+36), 242(-40), 255$ (+80), $297(-97) ;\left(S_{p}\right)-3: 217(+61), 231(-28), 242(+32), 255(-61)$, $296(+77)$

4,15-Bis-(4-(pyridin-4-yl)phenyl)[2.2]paracyclophane (4). Under an atmosphere of argon, ( $\mathrm{rac})-3(200 \mathrm{mg}, 0.327 \mathrm{mmol}, 1.00$ eq.), 4-pyridinylboronic acid $(92.4 \mathrm{mg}, \quad 0.752 \mathrm{mmol}, 2.30$ eq.), tris(dibenzylideneacetone)dipalladium(0)-chloroform $\quad(33.8 \mathrm{mg}$, $0.0327 \mathrm{mmol}, \quad 10.0 \mathrm{~mol} \%)$, tricyclohexylphosphine $(22.9 \mathrm{mg}$, $0.0818 \mathrm{mmol}, 25.0 \mathrm{~mol} \%)$ and potassium phosphate $(208 \mathrm{mg}$, $1.96 \mathrm{mmol}, 6.00$ eq.) were dissolved in 1,4-dioxane $(7.2 \mathrm{~mL})$ and water $(2.1 \mathrm{~mL})$. The reaction mixture was degassed at room temperature and then heated to reflux for $48 \mathrm{~h}$. After cooling to room temperature the solution was quenched by the addition of saturated aqueous ethylenediaminetetraacetic acid disodium salt solution and dichloromethane. The mixture was extracted with dichloromethane. The combined organic layers were washed with brine, dried with anhydrous magnesium sulphate and the solvent was removed under reduced pressure. The crude product was subjected to flash column chromatography on silica gel (cyclohexane/ethyl acetate $1: 1+0.5 \%$ triethylamine) and on reversed-phase silica gel (chloroform/methanol 1:1) to give (rac)-4 (82.9 mg, $0.161 \mathrm{mmol}, 49 \%)$ as a white solid. ${ }^{1} \mathrm{H}$ NMR $(500.1 \mathrm{MHz}$, $\left.\mathrm{CD}_{2} \mathrm{Cl}_{2}, 298 \mathrm{~K}\right): \delta[\mathrm{ppm}]=8.70-8.66(\mathrm{~m}, 4 \mathrm{H}, \mathrm{H}-23), 7.82-7.80(\mathrm{~m}, 4 \mathrm{H}$, $\mathrm{H}-19)$, 7.66-7.64 (m, 4H, H-18) 7.63-7.61 (m, 4H, H-22), 6.79 (d, $2 \mathrm{H}$, $\left.\mathrm{H}-5, \mathrm{H}-16,{ }^{4} J_{5,7}={ }^{4} J_{16,12}=1.9 \mathrm{~Hz}\right), 6.75\left(\mathrm{~d}, 2 \mathrm{H}, \mathrm{H}-8, \mathrm{H}-13,{ }^{3} J_{8,7}={ }^{3} J_{13,12}\right.$ $=7.8 \mathrm{~Hz}$ ), $6.66\left(\mathrm{dd}, 2 \mathrm{H}, \mathrm{H}-7, \mathrm{H}-12,{ }^{3} J_{7,8}=3 J_{12,13}=7.8 \mathrm{~Hz},{ }^{4} J_{7,5}=4 J_{12,16}=\right.$ $1.9 \mathrm{~Hz}), 3.31-3.20(\mathrm{~m}, 4 \mathrm{H}, \mathrm{H}-1, \mathrm{H}-2, \mathrm{H}-9, \mathrm{H}-10), 3.18-3.10(\mathrm{~m}, 2 \mathrm{H}$, $\mathrm{H}-9, \mathrm{H}-10), 2.61-2.53(\mathrm{~m}, 2 \mathrm{H}, \mathrm{H}-1, \mathrm{H}-2) .{ }^{13} \mathrm{C} N M R(125.8 \mathrm{MHz}$, $\left.\mathrm{CD}_{2} \mathrm{Cl}_{2}, 298 \mathrm{~K}\right): \delta[\mathrm{ppm}]=150.9(\mathrm{C}-23), 148.3(\mathrm{C}-21), 142.6(\mathrm{C}-17)$, 142.2 (C-4, C-15), 140.6 (C-6, C-11), 138.1 (C-3, C-14), 137.1 (C-20), 133.0 (C-8, C-13), 132.4 (C-5, C-16), 132.1 (C-7, C-12), 130.9 (C-18), 127.7 (C-19), 122.0 (C-22), 35.6 (C-9, C-10), 34.0 (C-1, C-2). MS (ESI+) $\mathrm{m} / \mathrm{z}: 515.2475[\mathbf{4 + H}]^{+}, 258.1273[4+2 \mathrm{H}]^{2+}$; HR-MS (ESI+) $\mathrm{m} / \mathrm{z}$ : calculated for $\mathrm{C}_{38} \mathrm{H}_{31} \mathrm{~N}_{2}[4+\mathrm{H}]^{+}$: 515.2482, found: 515.2475 . Elementary analysis: calculated for $\mathrm{C}_{38} \mathrm{H}_{30} \mathrm{~N}_{2} \cdot 1 / 6 \mathrm{CH}_{2} \mathrm{Cl}_{2}$ : C: $86.69, \mathrm{H}$ : $5.78, \mathrm{~N}: 5.30$, found: $\mathrm{C}: 86.83, \mathrm{H}: 6.00, \mathrm{~N}: 5.21$. Melting point: $240{ }^{\circ} \mathrm{C}$ (decomp.). $R_{f}$ (cyclohexane/ethyl acetate $1: 1+0.5 \%$ triethylamine): 0.12. UV-Vis $\left(\mathrm{CH}_{3} \mathrm{CN}, \mathrm{c}=19.4 \mu \mathrm{M}\right): \lambda[\mathrm{nm}]=261$, 302. $\mathrm{HPLC}$ (analytical, CHIRALPAK ${ }^{\circledast} \mathrm{IA}$, dichloromethane/ethanol (95:5 v/v), $1 \mathrm{~mL} / \mathrm{min}):\left(S_{\mathrm{p}}\right)-4 t_{R}=3.69 \mathrm{~min},\left(R_{\mathrm{p}}\right)-4 t_{R}=5.65 \mathrm{~min}$. HPLC semipreparative (CHIRALPAK ${ }^{\circledast} \mathrm{IA}$, dichloromethane/ethanol $(95: 5 \mathrm{v} / \mathrm{v})$, $15 \mathrm{~mL} / \mathrm{min}):\left(S_{\mathrm{p}}\right)-4>99 \%$ ee, $\left(R_{\mathrm{p}}\right)-498 \%$ ee. Specific rotation: $(-)-\left(S_{p}\right)-4:[\alpha]_{D}^{20}=-656^{\circ}\left(\mathrm{c}=2.00 \mathrm{mg} / \mathrm{mL}=3.89 \mathrm{~mm}, \mathrm{CH}_{2} \mathrm{Cl}_{2}\right),(+)-\left(R_{p}\right)-$ 4: $[\alpha]_{D}^{20}=+619^{\circ}\left(\mathrm{c}=2.00 \mathrm{mg} / \mathrm{mL}=3.89 \mathrm{mM}, \mathrm{CH}_{2} \mathrm{Cl}_{2}\right) . \mathrm{CD}\left(\mathrm{CH}_{3} \mathrm{CN}, \mathrm{c}=\right.$
$194 \mu \mathrm{M}): \lambda[\mathrm{nm}](\Delta \varepsilon[\mathrm{L} /(\mathrm{mol} \mathrm{cm})])=\left(R_{\mathrm{p}}\right)-4: 212(-9), 236(+31), 247$ (+11), $266(+38), 313(-87) ;\left(S_{p}\right)-4: 211(+5), 236(-27), 247(-9), 266$ $(-34), 313(+83)$.

4,15-Bis-(4-(pyridin-3-yl)phenyl)[2.2]paracyclophane (5). Under an atmosphere of argon, $(\mathrm{rac})-/\left(R_{\mathrm{p}}\right)-/\left(S_{\mathrm{p}}\right)-3(150 \mathrm{mg}, 0.245 \mathrm{mmol}$, 1.00 eq.), 3-pyridinylboronic acid (69.3 $\mathrm{mg}, 0.564 \mathrm{mmol}, 2.30$ eq.), tris(dibenzylideneacetone)dipalladium(0)-chloroform (25.4 mg, $0.0245 \mathrm{mmol}, 10.0 \mathrm{~mol} \%)$, tricyclohexylphosphine $(17.2 \mathrm{mg}$, $0.0613 \mathrm{mmol}, 25.0 \mathrm{~mol} \%)$ und potassium phosphate $(156 \mathrm{mg}$, $1.47 \mathrm{mmol}, 6.00$ eq.) were dissolved in 1,4-dioxane $(7.2 \mathrm{~mL})$ and water $(2.1 \mathrm{~mL})$. The reaction mixture was degassed at room temperature and then, heated to reflux for $48 \mathrm{~h}$. After cooling to room temperature the solution was quenched by the addition of saturated aqueous ethylenediaminetetraacetic acid disodium salt solution and dichloromethane. The mixture was extracted with dichloromethane. The combined organic layers were washed with brine, dried with anhydrous magnesium sulphate and the solvent was removed under reduced pressure. The crude product was subjected to flash column chromatography on silica gel (cyclohexane/ethyl acetate $1: 1+0.5 \%$ triethylamine) to give (rac)$/\left(R_{\mathrm{p}}\right)-/\left(\mathrm{S}_{\mathrm{p}}\right)-5(98.9 \mathrm{mg}, 0.192 \mathrm{mmol}, 78 \%)$ as a white solid. ${ }^{1} \mathrm{H} \mathrm{NMR}$ $\left(500.1 \mathrm{MHz}, \mathrm{CD}_{2} \mathrm{Cl}_{2}, 298 \mathrm{~K}\right): \delta[\mathrm{ppm}]=8.94$ (dd, $2 \mathrm{H}, \mathrm{H}-25,4 J_{25,22}=$ $\left.2.4 \mathrm{~Hz}, 5 J_{25,23}=0.9 \mathrm{~Hz}\right), 8.59\left(\mathrm{dd}, 2 \mathrm{H}, \mathrm{H}-24,3 J_{24,23}=4.8 \mathrm{~Hz}, 4 J_{24,22}=\right.$ $1.6 \mathrm{~Hz}$ ), 7.99 (ddd, $2 \mathrm{H}, \mathrm{H}-22,{ }^{3} J_{22,23}=7.9 \mathrm{~Hz},{ }^{4} J_{22,25}=2.4 \mathrm{~Hz},{ }^{4} J_{22,24}=$ 1.6 Hz), 7.76-7.73 (m, $4 \mathrm{H}, \mathrm{H}-19), 7.65-7.62(\mathrm{~m}, 4 \mathrm{H}, \mathrm{H}-18), 7.41$ (ddd, $\left.2 \mathrm{H}, \mathrm{H}-23,3 J_{23,22}=7.9 \mathrm{~Hz}, 3 J_{23,24}=4.8 \mathrm{~Hz}, 5 J_{23,25}=0.9 \mathrm{~Hz}\right), 6.79(\mathrm{~d}, 2 \mathrm{H}$, $\left.\mathrm{H}-5, \mathrm{H}-16,{ }^{4} J_{5,7}={ }^{4} J_{16,12}=1.9 \mathrm{~Hz}\right), 6.76\left(\mathrm{~d}, 2 \mathrm{H}, \mathrm{H}-8, \mathrm{H}-13,{ }^{3} J_{8,7}={ }^{3} J_{13,12}\right.$ $=7.8 \mathrm{~Hz}), 6.65\left(\mathrm{dd}, 2 \mathrm{H}, \mathrm{H}-7, \mathrm{H}-12,{ }^{3} J_{7,8}=3 J_{12,13}=7.8 \mathrm{~Hz},{ }^{4} J_{7,5}=4 J_{12,16}=\right.$ $1.9 \mathrm{~Hz}), 3.30-3.21(\mathrm{~m}, 4 \mathrm{H}, \mathrm{H}-1, \mathrm{H}-2, \mathrm{H}-9, \mathrm{H}-10), 3.17-3.10(\mathrm{~m}, 2 \mathrm{H}$, $\mathrm{H}-9, \mathrm{H}-10), 2.63-2.54(\mathrm{~m}, 2 \mathrm{H}, \mathrm{H}-1, \mathrm{H}-2) .{ }^{13} \mathrm{C}$ NMR $(125.8 \mathrm{MHz}$, $\left.\mathrm{CD}_{2} \mathrm{Cl}_{2}, 298 \mathrm{~K}\right): \delta[\mathrm{ppm}]=149.1(\mathrm{C}-24), 148.8(\mathrm{C}-25), 142.3(\mathrm{C}-4, \mathrm{C}-$ 15), 141.5 (C-17), 140.5 (C-6, C-11), 138.1 (C-3, C-14), 136.9 (C-20), 136.7 (C-21), 134.6 (C-22), 133.0 (C-8, C-13), 132.4 (C-5, C-16), 132.0 (C-7, C-12), 130.9 (C-18), 127.8 (C-19), 124.1 (C-23), 35.6 (C-9, C-10), 34.0 (C-1, C-2). MS (ESI+) m/z: $515.2480[5+\mathrm{H}]^{+}, 258.1277[5+2 \mathrm{H}]^{2+}$; HR-MS (ESI+) $\mathrm{m} / \mathrm{z}$ : calculated for $\mathrm{C}_{38} \mathrm{H}_{31} \mathrm{~N}_{2}[5+\mathrm{H}]^{+*}: 515.2482$, found: 515.2480. Elementary analysis: calculated for $\mathrm{C}_{38} \mathrm{H}_{30} \mathrm{~N}_{2} \cdot 2 \mathrm{C}_{6} \mathrm{H}_{6} \cdot 2 \frac{1}{2}$ $\mathrm{H}_{2} \mathrm{O}: \mathrm{C}: 86.69, \mathrm{H}: 5.78, \mathrm{~N}: 5.30$, found: C: $86.83, \mathrm{H}: 6.00, \mathrm{~N}: 5.21$. Melting point: $255{ }^{\circ} \mathrm{C}$ (decomp.). HPLC semi-preparative (CHIRALPAK ${ }^{\circledast} \mathrm{IA}$, dichloromethane/ethanol (95:5 v/v), $\left.15 \mathrm{~mL} / \mathrm{min}\right)$ : $\left(S_{\mathrm{p}}\right)-4>99 \%$ ee, $\left(R_{\mathrm{p}}\right)-4$ 98\% ee. UV-Vis $\left(\mathrm{CH}_{3} \mathrm{CN}, \mathrm{c}=19.4 \mu \mathrm{M}\right): \lambda[\mathrm{nm}]$ $=256$, 298. Specific rotation: $(-)-\left(R_{\mathrm{p}}\right)-5:[\alpha]_{D}^{23}=-570^{\circ}(\mathrm{c}=2.00$ $\left.\mathrm{mg} / \mathrm{mL}=5.83 \mathrm{mM}, \mathrm{CH}_{2} \mathrm{Cl}_{2}\right),(+)-\left(S_{\mathrm{p}}\right)-5:[\alpha]_{D}^{23}=+556^{\circ}(\mathrm{c}=2.00 \mathrm{mg} / \mathrm{mL}$ $\left.=5.83 \mathrm{~mm}, \mathrm{CH}_{2} \mathrm{Cl}_{2}\right) \cdot \mathrm{CD}\left(\mathrm{CH}_{3} \mathrm{CN}, \mathrm{c}=194 \mu \mathrm{m}\right): \lambda[\mathrm{nm}](\Delta \varepsilon[\mathrm{L} /(\mathrm{mol} \mathrm{cm})])$ $=\left(R_{\mathrm{p}}\right)-5: 217(-41), 234(+64), 248(+11), 263(+49), 310(-118) ;\left(S_{\mathrm{p}}\right)-$ 5: $217(+43), 231(-68), 247(-11), 263(-51), 311(+125)$.

\section{Complexation procedures}

$\left[\mathrm{Pd}_{2}(\mathrm{dppp})_{2}(\mathbf{4})_{2}\right](\mathrm{OTf})_{4}$. $(\mathrm{rac})$-, $\left(R_{\mathrm{p}}\right)-$ or $\left(S_{\mathrm{p}}\right)-\mathbf{4}(2.05 \mathrm{mg}, 3.98 \mu \mathrm{mol}$, 1.00 eq.) was dissolved in deuterated acetonitrile $(0.5 \mathrm{~mL})$ and a solution of $[\mathrm{Pd}(\mathrm{dppp})(\mathrm{OTf})]_{2}(3.27 \mathrm{mg}, 4.00 \mu \mathrm{mol}, 1.01 \mathrm{eq}$.$) \quad in$ deuterated acetonitrile $(0.1 \mathrm{~mL})$ was added. The mixture was filtrated. $\left[\mathrm{Pd}_{2}(\mathrm{dppp})_{2}\left\{\left(R_{\mathrm{p}}\right)-4\right\}_{2}\right](\mathrm{OTf})_{4}:{ }^{1} \mathrm{H}$ NMR $\left(499.1 \mathrm{MHz}, \mathrm{CD}_{3} \mathrm{CN}\right.$, $298 \mathrm{~K}): \delta[\mathrm{ppm}]=8.59-8.53(\mathrm{~m}, 8 \mathrm{H}, \mathrm{H}-23), 7.72-7.52(\mathrm{~m}, 40 \mathrm{H}, \mathrm{H}-18$, H-19, dppp-Ph ortho, dppp-Ph $\left._{\text {para }}\right)$, 7.48-7.36 (m, 24H, H-22, dppp$\left.\mathrm{Ph}_{\text {meta }}\right)$, 6.78-6.70 (m, 8H, H-5, H-7, H-12, H-16), 6.69-6.64 (m, 4H, $\mathrm{H}-8, \mathrm{H}-13)$, 3.32-2.94 (m, 24H, H-1, H-2, H-9, H-10, dppp- $\mathrm{CH}_{2}-\mathrm{PPh}_{2}$ ), 2.33-2.17 (m, 4H, dppp- $\mathrm{CH}_{2}$ ). ${ }^{13} \mathrm{C}$ NMR (125.5 MHz, $\left.\mathrm{CD}_{3} \mathrm{CN}, 298 \mathrm{~K}\right)$ : 
$\delta[\mathrm{ppm}]=150.8(\mathrm{C}-23), 144.2^{*}, 141.5^{*}, 138.1^{*}, 134.1^{*}, 133.6^{*}$, $133.3^{*}, 132.5^{*}, 131.4^{*}, 130.4^{*}, 128.4^{*}, 126.0^{*}, 124.5^{*}, 123.5^{*}$, 120.9*, 35.4* 34.2*. *Signals could not be unambiguously assigned. ${ }^{31} \mathrm{P}-\mathrm{NMR}\left(202.1 \mathrm{MHz}, \mathrm{CD}_{3} \mathrm{CN}, 298 \mathrm{~K}\right): \delta[\mathrm{ppm}]=8.65(\mathrm{~s}$, dppp-P). ${ }^{1} \mathrm{H}$-DOSY-NMR $\left(499.1 \mathrm{MHz}, \mathrm{CD}_{3} \mathrm{CN}, \quad 298 \mathrm{~K}\right): \quad D=$ $5.15 \cdot 10^{-10} \mathrm{~m}^{2} \mathrm{~s}^{-1}, \quad R_{H}=13.2 \AA . \quad \mathrm{MS} \quad(\mathrm{ESI}+) \quad \mathrm{m} / \mathrm{z}: \quad 516.1512$ $\left[\mathrm{Pd}_{2}(\mathrm{dppp})_{2}\left\{\left(R_{\mathrm{p}}\right)-4\right\}_{2}\right]^{4+}$ and $\left[\mathrm{Pd}(\mathrm{dppp})\left\{\left(R_{\mathrm{p}}\right)-4\right\}\right]^{2+}, \quad 536.6639$ $\left[\mathrm{Pd}(\mathrm{dppp})\left\{\left(R_{\mathrm{p}}\right)-4\right\}\left(\mathrm{CH}_{3} \mathrm{CN}\right)\right]^{2+}, 667.0102\{[\mathrm{Pd}(\mathrm{dppp})] \mathrm{OTf}\}^{+}, 738.5190$ $\left\{\left[\mathrm{Pd}_{2}(\mathrm{dppp})_{2}\left\{\left(R_{\mathrm{p}}\right)-4\right\}_{2}\right] \mathrm{OTf}\right\}^{3+}, \quad 773.2728 \quad\left[\mathrm{Pd}(\mathrm{dppp}) \quad\left\{\left(R_{\mathrm{p}}\right)-4\right\}_{2}\right]^{2+}$, $1181.2550\left\{\left[\mathrm{Pd}_{2}(\mathrm{dppp})_{2}\left\{\left(R_{\mathrm{p}}\right)-4\right\}_{2}\right](\mathrm{OTf})_{2}\right\}^{2+}$ and $\left\{\left[\mathrm{Pd}(\mathrm{dppp})\left\{\left(R_{\mathrm{p}}\right)-\right.\right.\right.$ 4\}]OTf\}'. UV-Vis $\left(\mathrm{CH}_{3} \mathrm{CN}, \mathrm{c}=3.32 \mathrm{mM}\right): \lambda[\mathrm{nm}]=275,324 . \mathrm{CD}$ $\left(\mathrm{CH}_{3} \mathrm{CN}, \mathrm{c}=3.32 \mathrm{~mm}\right): \lambda[\mathrm{nm}](\Delta \varepsilon[\mathrm{L} /(\mathrm{mol} \mathrm{cm})])=\left[\mathrm{Pd}_{2}(\mathrm{dppp})_{2}\left\{\left(R_{\mathrm{p}}\right)-\right.\right.$ 4\} $\left.\}_{2}\right](\text { OTf })_{4}$ : $214(-25), 237(+120), 257(-3), 273(+53), 291(-1), 305$ $(+18), 338(-236) ;\left[\operatorname{Pd}_{2}(\mathrm{dppp})_{2}\left\{\left(S_{\mathrm{p}}\right)-4\right\}_{2}\right](\mathrm{OTf})_{4}: \quad 214 \quad(+33), 237$ $(-120), 258(+4), 272(-52), 291(+2), 304(-9), 337(+247)$. [Pd Pdppp $\left._{2}\{(\mathrm{rac})-4\}_{2}\right](\mathrm{OTf})_{4}:{ }^{1} \mathrm{H}$ NMR (499.1 MHz, CD 3 CN, $\left.298 \mathrm{~K}\right)$ : $\delta$ [ppm] $=8.59-8.53(\mathrm{~m}, 8 \mathrm{H}, \mathrm{H}-23), 7.72-7.52(\mathrm{~m}, 40 \mathrm{H}, \mathrm{H}-18, \mathrm{H}-19$, dppp- $\mathrm{Ph}_{\text {ortho, }}$ dppp- $\left.\mathrm{Ph}_{\text {para }}\right)$, 7.48-7.36 (m, 24H, H-22, dppp- $\left.\mathrm{Ph}_{\text {meta }}\right)$, 6.78-6.70 (m, 8H, H-5, H-7, H-12, H-16), 6.69-6.64 (m, 4H, H-8, $\mathrm{H}-13), 3.32-2.94\left(\mathrm{~m}, 24 \mathrm{H}, \mathrm{H}-1, \mathrm{H}-2, \mathrm{H}-9, \mathrm{H}-10, \mathrm{dppp}-\mathrm{CH}_{2}-\mathrm{PPh}_{2}\right), 2.33-$ $2.17\left(\mathrm{~m}, 4 \mathrm{H}, \mathrm{dppp}-\mathrm{CH}_{2}\right) .{ }^{13} \mathrm{C}$ NMR (125.5 MHz, CD $\left.{ }_{3} \mathrm{CN}, 298 \mathrm{~K}\right)$ : $\delta[\mathrm{ppm}]=150.7(\mathrm{C}-23), 144.1^{*}, 141.5^{*}, 138.1^{*}, 134.0^{*}, 133.5^{*}$, 133.3*, 132.9*, 131.4*, 130.5*, 128.4*, 126.0*, 124.6* 123.5*, 120.9*, 35.4*, 34.2*. *Signals could not be unambiguously assigned. ${ }^{31 \mathrm{P}} \mathrm{NMR}\left(202.1 \mathrm{MHz}, \mathrm{CD}_{3} \mathrm{CN}, 298 \mathrm{~K}\right): \delta[\mathrm{ppm}]=8.65(\mathrm{~s}$, dppp-P). ${ }^{1} \mathrm{H}-\mathrm{DOSY}$ NMR (499.1 $\left.\mathrm{MHz}, \mathrm{CD}_{3} \mathrm{CN}, \quad 298 \mathrm{~K}\right): D=$ $4.89 \cdot 10^{-10} \mathrm{~m}^{2} \mathrm{~s}^{-1}, \quad R_{H}=13.9 \AA \AA$. MS $(\mathrm{ESI}+) \mathrm{m} / \mathrm{z}: 516.1529$ $\left[\mathrm{Pd}_{2}(\mathrm{dppp})_{2}\{(\mathrm{rac})-4\}_{2}\right]^{4+}$ and $[\mathrm{Pd}(\mathrm{dppp})\{(\mathrm{rac})-4\}]^{2+}, \quad 536.1661$ $\left[\mathrm{Pd}(\mathrm{dppp})\{(\mathrm{rac})-4\}\left(\mathrm{CH}_{3} \mathrm{CN}\right)\right]^{2+}, \quad 595.1030 \quad\left\{\left[\mathrm{Pd}(\mathrm{dppp})\left(\mathrm{CH}_{3} \mathrm{CN}\right)\right] \mathrm{Cl}\right\}^{+}$, $667.0126\{[\mathrm{Pd}(\mathrm{dppp})] \mathrm{OTf}\}^{+}, 738.51220\left\{\left[\mathrm{Pd}_{2}(\mathrm{dppp})_{2}\{(\mathrm{rac})-4\}_{2}\right] \mathrm{OTf}\right\}^{3+}$, $773.2757\left[\mathrm{Pd}(\mathrm{dppp})\{(\text { rac })-4\}_{2}\right]^{2+}, \quad 1181.2600 \quad\left\{\left[\mathrm{Pd}_{2}(\mathrm{dppp})_{2}\{(\right.\right.$ rac $)-$ $\left.\left.4\}_{2}\right](\mathrm{OTf})_{2}\right\}^{2+}$ and $\{[\mathrm{Pd}(\mathrm{dppp})\{(\text { rac })-4\}] \mathrm{OTf}\}^{+}$.

$\left[\mathrm{Pd}_{2} \mathbf{5}_{4}\right]\left(\mathrm{BF}_{4}\right)_{4}$. $(\mathrm{rac})-,\left(R_{\mathrm{p}}\right)-$ or $\left(S_{\mathrm{p}}\right)-5$ (4.00 mg, $7.77 \mu \mathrm{mol}, 1.00$ eq.) was dissolved in deuterated acetonitrile $(1 \mathrm{~mL})$ and a solution of $\left[\mathrm{Pd}\left(\mathrm{CH}_{3} \mathrm{CN}\right)_{4}\right]\left(\mathrm{BF}_{4}\right)_{2} \quad(1.76 \mathrm{mg}, 3.96 \mu \mathrm{mol}, 0.51$ eq. $)$ in deuterated acetonitrile $(0.5 \mathrm{~mL})$ was added. The mixture was stirred at $70^{\circ} \mathrm{C}$ for $15 \mathrm{~h}$ and then filtrated. $\left[\operatorname{Pd}_{2}\left\{\left(R_{\mathrm{p}}\right)-5_{4}\right\}\right]\left(\mathrm{BF}_{4}\right)_{4}:{ }^{1} \mathrm{H}$ NMR $(499.1 \mathrm{MHz}$, $\left.\mathrm{CD}_{3} \mathrm{CN}, 298 \mathrm{~K}\right): \delta[\mathrm{ppm}]=\delta[\mathrm{ppm}]=9.47\left(\mathrm{~d}, 8 \mathrm{H}, \mathrm{H}-25,4 J_{25,22}=\right.$ $2.0 \mathrm{~Hz}$ ), $9.13\left(\mathrm{dd}, 8 \mathrm{H}, \mathrm{H}-24,3 J_{24,23}=5.7 \mathrm{~Hz}, 4 J_{24,22}=1.3 \mathrm{~Hz}\right.$ ), 8.32 (ddd, $8 \mathrm{H}, \mathrm{H}-22,3 J_{22,23}=8.00 \mathrm{~Hz},{ }^{4} J_{22,25}=2.0 \mathrm{~Hz},{ }^{4} J_{22,24}=1.3 \mathrm{~Hz}$ ), 7.75 $\left(\mathrm{dd}, 8 \mathrm{H}, \mathrm{H}-23,{ }^{3} \mathrm{~J}_{23,22}=8.0 \mathrm{~Hz}, 3 \mathrm{~J}_{23,24}=5.7 \mathrm{~Hz}\right), 7.68-7.65(\mathrm{~m}, 16 \mathrm{H}$, $\mathrm{H}-19), 7.65-7.62(\mathrm{~m}, 16 \mathrm{H}, \mathrm{H}-18), 6.75$ (d, 8H, H-5, H-16, $4 J_{5,7}=4 J_{16,12}$ $=1.5 \mathrm{~Hz}), 6.64-6.59(\mathrm{~m}, 16 \mathrm{H}, \mathrm{H}-8, \mathrm{H}-13, \mathrm{H}-7, \mathrm{H}-12), 3.42-3.34(\mathrm{~m}$, $8 \mathrm{H}, \mathrm{H}-1, \mathrm{H}-2), 3.25-3.17(\mathrm{~m}, 8 \mathrm{H}, \mathrm{H}-9, \mathrm{H}-10), 3.06-3.97$ (m, 8H, H-9, $\mathrm{H}-10), 2.51-2.42(\mathrm{~m}, 8 \mathrm{H}, \mathrm{H}-1, \mathrm{H}-2) .{ }^{13} \mathrm{C} N M R\left(125.5 \mathrm{MHz}, \mathrm{CD}_{3} \mathrm{CN}\right.$, $298 \mathrm{~K}): \delta[\mathrm{ppm}]=150.9$ (C-24), 149.7 (C-25), 143.2 (C-17), 141.8 (C-4, C-15), 141.7 (C-6, C-11), 140.9 (C-21), 140.3 (C-22), 137.5 (C-3, C-14), 134.6 (C-20), 133.5* (C-7, C-8, C-12, C-13), 133.1 (C-5, C-16), 132.6* (C-7, C-8, C-12, C-13), 131.5 (C-19), 128.6 (C-23), 128.5 (C-18), 35.3 (C-9, C-10), 34.8 (C-1, C-2). * Signals could not be unambiguously assigned. ${ }^{19} \mathrm{~F}$ NMR (469.6 MHz, $\mathrm{CD}_{3} \mathrm{CN}, 298 \mathrm{~K}$ ): $\delta$ [ppm] $=-151.74 \quad\left(\mathrm{~s}, \quad \mathrm{BF}_{4}\right), \quad-151.79 \quad\left(\mathrm{~s}, \quad \mathrm{BF}_{4}\right) .{ }^{1} \mathrm{H}-\mathrm{DOSY} \quad \mathrm{NMR}$ $\left(499.1 \mathrm{MHz}, \mathrm{CD}_{3} \mathrm{CN}, 298 \mathrm{~K}\right): D=5.49 \cdot 10^{-10} \mathrm{~m}^{2} \mathrm{~s}^{-1}, R_{H}=10.2 \AA . \mathrm{MS}$ $(\mathrm{ESI}+) \quad m / z: \quad 567.7\left[\mathrm{Pd}_{2}\left\{\left(R_{\mathrm{p}}\right)-5_{4}\right\}_{4}\right]^{4+}, \quad 786.0\left\{\left[\mathrm{Pd}_{2}\left\{\left(R_{\mathrm{p}}\right)-5_{4}\right\}_{4}\right]\left(\mathrm{BF}_{4}\right)\right\}^{3+}$, $1222.5\left\{\left[\mathrm{Pd}_{2}\left\{\left(R_{\mathrm{p}}\right)-5\right\}\left(\mathrm{BF}_{4}\right)_{2}\right\}^{2+}\right.$. UV-Vis $\left(\mathrm{CH}_{3} \mathrm{CN}, \mathrm{c}=3.24 \mathrm{~mm}\right): \lambda[\mathrm{nm}]=$ 275, 324. $\mathrm{CD}\left(\mathrm{CH}_{3} \mathrm{CN}, \mathrm{c}=3.24 \mathrm{~mm}\right): \lambda[\mathrm{nm}](\Delta \varepsilon[\mathrm{L} /(\mathrm{mol} \mathrm{cm})])=$
$\left[\mathrm{Pd}_{2}\left\{\left(R_{\mathrm{p}}\right)-5\right\}_{4}\right]\left(\mathrm{BF}_{4}\right)_{4}: 211(-66), 236(+137), 249(+102), 259(+107)$, $272(+53), 282(+63), 323(-470) ;\left[\mathrm{Pd}_{2}\left\{\left(\mathrm{~S}_{\mathrm{p}}\right)-5\right\}_{4}\right]\left(\mathrm{BF}_{4}\right)_{4}: 212(+52), 236$ $(-101), 248(-70), 255(-72), 271(-11), 285(-34), 322(+358)$. $\left[\mathrm{Pd}_{2}\left\{(\mathrm{rac})-5_{4}\right\}\right]\left(\mathrm{BF}_{4}\right)_{4}:{ }^{19} \mathrm{~F} \quad \mathrm{NMR} \quad\left(469.6 \mathrm{MHz}, \mathrm{CD}_{3} \mathrm{CN}, \quad 298 \mathrm{~K}\right)$ : $\delta[\mathrm{ppm}]=-151.60 \quad\left(\mathrm{~s}, \mathrm{BF}_{4}\right), \quad-151.65 \quad\left(\mathrm{~s}, \mathrm{BF}_{4}\right) .{ }^{1} \mathrm{H}-\mathrm{DOSY} \quad \mathrm{NMR}$ $\left(700.4 \mathrm{MHz}, \mathrm{CD}_{3} \mathrm{CN}, 298 \mathrm{~K}\right): D=6.52 \cdot 10^{-10} \mathrm{~m}^{2} \mathrm{~s}^{-1}, R_{H}=10.4 \AA . \mathrm{MS}$ $(\mathrm{ESI}+) \quad \mathrm{m} / \mathrm{z}: \quad 567.8\left[\mathrm{Pd}_{2}\{(\mathrm{rac})-5\}_{4}\right]^{4+}, 786.0\left\{\left[\mathrm{Pd}_{2}\{(\mathrm{rac})-5\}_{4}\right]\left(\mathrm{BF}_{4}\right)\right\}^{3+}$, $1222.5\left\{\left[\mathrm{Pd}_{2}\{(\mathrm{rac})-5\}_{4}\right]\left(\mathrm{BF}_{4}\right)_{2}\right\}^{2+}$.

\section{X-ray crystallography}

X-Ray experimental details for $\left(R_{\mathrm{p}}\right)-\mathbf{4}$, the racemic mixture of $\left[\mathrm{Pd}_{2}(\mathrm{dppp})_{2}\left\{\left(R_{\mathrm{p}}\right)-4\right\}_{2}\right](\mathrm{OTf})_{4} \quad \& \quad\left[\mathrm{Pd}_{2}(\mathrm{dppp})_{2}\left\{\left(\mathrm{~S}_{\mathrm{p}}\right)-4\right\}_{2}\right](\mathrm{OTf})_{4}$ and $\left[\mathrm{Pd}_{2}\left\{\left(R_{\mathrm{p}}\right)-5\right\}_{4}\right]\left(\mathrm{BF}_{4}\right)_{4}$ are shown in supporting information. The single-crystal X-ray data for $\left(R_{\mathrm{p}}\right)-\mathbf{4}$ were measured on a Rigaku SuperNova diffractometer equipped with an EOS CCD detector using mirror-monochromated Mo-Ka $(\lambda=0.71073 \AA)$ radiation. Data for the racemic mixture of $\left[\mathrm{Pd}_{2}(\mathrm{dppp})_{2}\left\{\left(R_{\mathrm{p}}\right)-4\right\}_{2}\right](\mathrm{OTf})_{4} \quad$ \& $\left[\mathrm{Pd}_{2}(\mathrm{dppp})_{2}\left\{\left(\mathrm{~S}_{\mathrm{p}}\right)-\mathbf{4}\right\}_{2}\right](\mathrm{OTf})_{4}$ and $\left[\mathrm{Pd}_{2}\left\{\left(R_{\mathrm{p}}\right)-5\right\}_{4}\right]\left(\mathrm{BF}_{4}\right)_{4} \quad$ were measured using a dual-source Rigaku SuperNova diffractometer equipped with an Atlas detector using mirrormonochromated $\mathrm{Cu}-\mathrm{K} \alpha(\lambda=1.54184 \AA$ $)$ radiation. The data collection and reduction were performed using the program CrysAlisPro ${ }^{19}$ and Gaussian face index absorption correction method was applied. ${ }^{19}$ The structure was solved with direct methods (SHELXS) ${ }^{20}$ and refined by full-matrix least squares on $F^{2}$ using the OLEX2 ${ }^{21}$ software, which utilizes the SHELXL-2015 module. ${ }^{21}$ In $\left[\mathrm{Pd}_{2}\left\{\left(R_{\mathrm{p}}\right)-5\right\}_{4}\right]\left(\mathrm{BF}_{4}\right)_{4}$ one tetrafluoroborate anion could not be found using electron fourier difference map. This is due to weakly diffracting power of the crystals and disordered solvent molecules. Therefore, one tetrafluoroborate anion is modelled and thermal movement of fluorine atoms on both tetrafluoroborate anions were physically restrained to give roughly tetrahedral geometry. CCDC-1893943-1893945 contain the supplementary data for these structures. These data can be obtained free of charge via www.ccdc.cam.ac.uk/data_request/cif, or by emailing data_request@ccdc.cam.ac.uk, or by contacting The Cambridge Crystallographic Data Centre, 12, Union Road, Cambridge CB2 1EZ, UK; fax: +44 1223336033.

\section{Acknowledgements}

Authors acknowledge the Studienstiftung des deutschen Volkes for a doctoral scholarship and the Bonn International Graduate School of Chemistry for an international research scholarship (J.A.), the Academy of Finland (RP: 298817) and the University of Jyväskylä (KR), Finland for financial support. We thank Christine Sondag and Karin Peters-Pflaumbaum for their support in measuring the EI- and ESI-MS spectra.

\section{Notes and references}

1 a) A. Wu and L. Isaacs, J. Am. Chem. Soc., 2003, 125, 4831; b) K. Osowska and O. Miljanić, Synlett, 2011, 1643; c) M. M. Safont-Sempere, G. Fernández and F. Würthner, Chem. Rev., 2011, 111, 5784; d) M. Lal Saha and M. Schmittel, Org. Biomol. Chem., 2012, 10, 4651; e) Z. He, W. Jiang and C. A. 
Schalley, Chem. Soc. Rev., 2015, 44, 779; f) K. Acharyya, P. S. Mukherjee, Angew. Chem. Int. Ed., early view; DOI: 10.1002/anie.201900163.

2 T. W. Kim, J.-I. Hong and M. S. Lah, Chem. Commun., 2001, 743.

3 A. Shivanyuk and J. Rebek, J. Am. Chem. Soc., 2002, 124, 12074.

4 R. Krämer, J.-M. Lehn and A. Marquis-Rigault, Proc. Natl. Acad. Sci. USA, 1993, 90, 5394.

5 P. N. Taylor and H. L. Anderson, J. Am. Chem. Soc., 1999, 121, 11538.

6 a) M. Crego-Calama and D. N. Reinhoudt, Eds. Supramolecular Chirality, Springer Berlin Heidelberg, Berlin, Heidelberg, 2006; b) F. R. Keene, Ed., Chirality in Supramolecular Assemblies: Causes and Consequences, John Wiley \& Sons, Ltd, Chichester, UK, 2016;. c) H. Jędrzejewska and A. Szumna, Chem. Rev., 2017, 117, 4863.

7 a) D. K. Smith, Chem. Soc. Rev., 2009, 38, 684; b) T. F. A. De Greef, M. M. J. Smulders, M. Wolffs, A. P. H. J. Schenning, R. P. Sijbesma and E. W. Meijer, Chem. Rev., 2009, 109, 5687; c) K. Sato, Y. Itoh and T. Aida, Chem Sci., 2014, 5, 136; d) M. Liu, L. Zhang and T. Wang, Chem. Rev., 2015, 115, 7304.

8 Examples for narcissistic chiral self-sorting of ligands with chelating metal binding motifs: a) D. L. Caulder and K. N. Raymond, Angew. Chem. Int. Ed., 1997, 36, 1440; b) M. A. Masood, E. J. Enemark and T. D. P. Stack, Angew. Chem. Int. Ed., 1998, 37, 928; c) M. Albrecht, M. Schneider and H. Röttele, Angew. Chem. Int. Ed., 1999, 38, 557; d) J.-M. Vincent, C. Philouze, I. Pianet and J.-B. Verlhac, Chem. Eur. J., 2000, 6, 3595; e) A. Lützen, M. Hapke, J. Griep-Raming, D. Haase and W. Saak, Angew. Chem. Int. Ed., 2002, 41, 2086; f) M. Albrecht and R. Fröhlich, Bull. Chem. Soc. Jpn., 2007, 80, 797; g) U. Kiehne, T. Weilandt and A. Lützen, Org. Lett., 2007, 9, 1283; h) P. L. Arnold, J.-C. Buffet, R. P. Blaudeck, S. Sujecki, A. J. Blake and C. Wilson, Angew. Chem. Int. Ed., 2008, 47, 6033; i) J. Bunzen, T. Bruhn, G. Bringmann and A. Lützen, J. Am. Chem. Soc., 2009, 131, 3621; j) N. Dalla-Favera, U. Kiehne, J. Bunzen, S. Hytteballe, A. Lützen and C. Piguet, Angew. Chem. Int. Ed., 2010, 49, 125; k) C. Gütz, R. Hovorka, N. Struch, J. Bunzen, G. Meyer-Eppler, Z.-W. Qu, S. Grimme, F. Topić, K. Rissanen, M. Cetina, M. Engeser and A. Lützen, J. Am. Chem. Soc., 2014, 136, 11830; I) L.-L. Yan, C.-H. Tan, G.-L. Zhang, L.-P. Zhou, J.-C. Bünzli, Q.-F. Sun, J. Am. Chem. Soc., 2015, 137, 8550-8555; m) A. Jarzebski, C. Tenten, C. Bannwarth, G. Schnakenburg, S. Grimme and A. Lützen, Chem. Eur. J., 2017, 23, 12380; n) N. Struch, C. Frömbgen, G. Schnakenburg and A. Lützen, Eur. J. Org. Chem., 2017, 4984.

9 Examples for narcissistic chiral self-sorting of ligands with monodentate metal binding motifs: a) L. Isaacs and D. Witt, Angew. Chem. Int. Ed., 2002, 41, 1905; b) H.-J. Kim, D. Moon, M. S. Lah and J.-I. Hong, Angew. Chem. Int. Ed., 2002, 41, 3174; c) I.-W. Hwang, T. Kamada, T. K. Ahn, D. M. Ko, T. Nakamura, A. Tsuda, A. Osuka and D. Kim, J. Am. Chem. Soc., 2004, 126, 16187; d) T. J. Burchell and R. J. Puddephatt, Inorg. Chem., 2006, 45, 650; e) T. Kamada, N. Aratani, T. Ikeda, N. Shibata, Y. Higuchi, A. Wakamiya, S. Yamaguchi, K. S. Kim, Z. S. Yoon, D. Kim and A. Osuka, J. Am. Chem. Soc., 2006, 128, 7670; f) C. Maeda, T. Kamada, N. Aratani and A. Osuka, Coord. Chem. Rev. 2007., 251, 2743; g) T. K. Ronson, J. Fisher, L. P. Harding and M. J. Hardie, Angew. Chem. Int. Ed., 2007, 46, 9086; h) K. Schober, H. Zhang and R. M. Gschwind, J. Am. Chem., Soc. 2008, 130, 12310; i) C. Gütz, R. Hovorka, G. Schnakenburg and A. Lützen, Chem. Eur. J., 2013, 19, 10890; j) C. Gütz, R. Hovorka, C. Stobe, N. Struch, F. Topić, G. Schnakenburg, K. Rissanen and A. Lützen, Eur. J. Org. Chem., 2014, 206; k) G. Meyer-Eppler, F. Topić, G. Schnakenburg, K. Rissanen and A. Lützen, Eur. J. Inorg. Chem., 2014, 2495; I) R. Hovorka, S. Hytteballe, T. Piehler, G. Meyer-Eppler, F. Topić, K.
Rissanen, M. Engeser and A. Lützen, Beilstein J. Org. Chem., 2014, 10, 432

10 Examples for social chiral self-sorting of ligands with chelating metal binding motifs: a) M. Kitamura, S. Okada, S. Suga and R. Noyori, J. Am. Chem. Soc., 1989, 111, 4028; b) H. C. Aspinall, J. F. Bickley, J. L. M. Dwyer, N. Greeves, R. V. Kelly and A. Steiner, Organometallics, 2000, 19, 5416; c) R. Wang, M. Hong, D. Yuan, Y. Sun, L. Xu, J. Luo, R. Cao and A. S. C. Chan, Eur. J. Inorg. Chem., 2004, 37; d) J. M. Takacs, P. M. Hrvatin, J. M. Atkins, D. S. Reddy and J. L. Clark, New J. Chem., 2005, 29, 263.

11 Examples for social chiral self-sorting of ligands with monodentate metal binding motifs: a) T. W. Kim, J.-I. Hong and M. S. Lah, Chem. Commun., 2001, 743; b) C. G. Claessens and T. Torres, J. Am. Chem. Soc., 2002, 124, 14522; c) T. J. Burchell and R. J. Puddephatt, Inorg. Chem., 2005, 44, 3718; d) M. Mizumura, H. Shinokubo and A. Osuka, Angew. Chem. Int. Ed., 2008, 47, 5378; e) C. G. Claessens, I. Sánchez-Molina and T. Torres, Supramol. Chem., 2009, 21, 44; f) T. Weilandt, U. Kiehne, G. Schnakenburg and A. Lützen, Chem. Commun., 2009, 2320; g) T. Weilandt, U. Kiehne, J. Bunzen, G. Schnakenburg and A. Lützen, Chem. Eur. J., 2010, 16, 2418; h) J. J. Henkelis, C. J. Carruthers, S. E. Chambers, R. Clowes, A. I. Cooper, J. Fisher and M. J. Hardie, J. Am. Chem. Soc., 2014, 136, 14393.

12 G. Meyer-Eppler, R. Sure, A. Schneider, G. Schnakenburg, S. Grimme and A. Lützen, J. Org. Chem., 2014, 79, 6679.

13 a) G. Meyer-Eppler, E. Vogelsang, C. Benkhäuser, A. Schneider, G. Schnakenburg and A. Lützen, Eur. J. Org. Chem., 2013, 4523; b) V. Göker, S. R. Kohl, F. Rominger, G. MeyerEppler, L. Volbach, G. Schnakenburg, A. Lützen, A. S. K. Hashmi, J. Organomet. Chem., 2015, 795, 45.

14 a) V. K. Jain and L. Jain, Coord. Chem. Rev., 2010, 254, 2848; b) R. Chakrabarty, P. S. Mukherjee and P. J. Stang, Chem. Rev., 2011, 111, 6810; c) Y. Inokuma, M. Kawano and M. Fujita, Nat. Chem. 2011, 3, 349; d) H. Amouri, C. Desmarets and J. Moussa, Chem. Rev., 2012, 112, 2015; e) N. B. Debata, D. Tripathy and D. K. Chand, Coord. Chem. Rev., 2012, 256, 1831; f) d) M. Han, D. M. Engelhard and G. H. Clever, Chem. Soc. Rev. 2014, 43, 1848; g) T. R. Cook, and P. J. Stang, Chem. Rev., 2015, 115, 7001.

15 S. S. Zalesskiy and V. P. Ananikov, Organomet., 2012, 31, 2302.

16 T. G. Appleton, M. A. Bennett and I. B. Tomkins, J. Chem. Soc. Dalton Trans., 1976, 439.

17 P. J. Stang, D. H. Cao, S. Saito and A. M. Arif, J. Am. Chem. Soc., 1995, 117, 6273.

18 a) K. E. Van Holde, Physical Biochemistry, Prentice-Hall, Englewood Cliffs (1971); b) A. Macchioni, G. Ciancaleoni, C. Zuccaccia, D. Zuccaccia, Chem. Soc. Rev., 2008, 37, 479.

19 Rigaku Oxford Diffraction, 2017, CrysAlisPro Software system, version 38.46, Rigaku Corporation, Oxford, UK.

20 a) G. M. Sheldrick, Acta Crystallogr. Sect. C, 2015, 71, 3; b) G. M. Sheldrick, Acta Crystallogr. Sect. A, 2015, 71, 3.

21 O. V Dolomanov, L. J. Bourhis, R. J. Gildea, J. A. K. Howard and H. Puschmann, J. Appl. Crystallogr., 2009, 42, 339. 